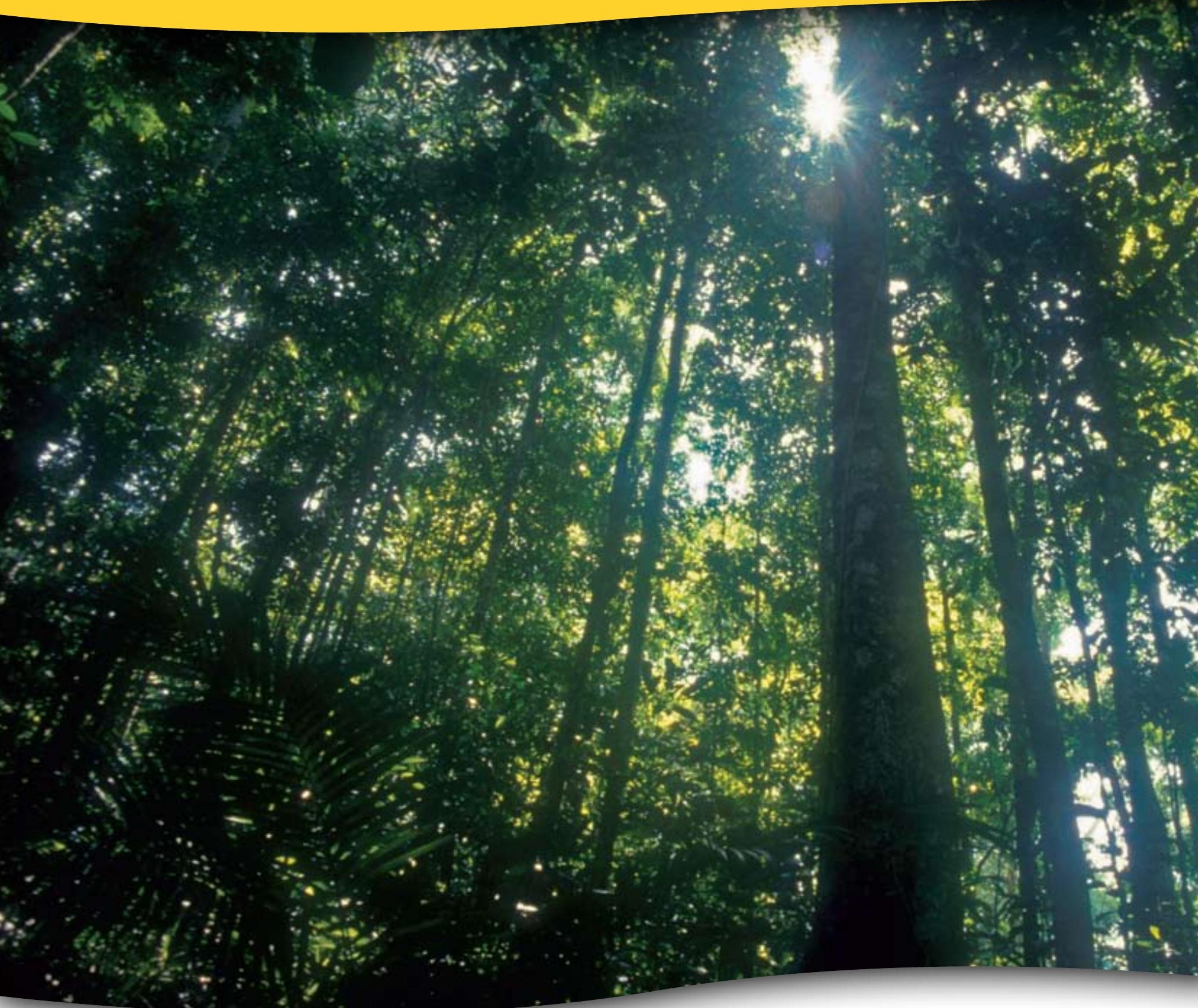

\title{
Emerging REDD+
}

A preliminary survey of demonstration and readiness activities

Sheila Wertz-Kanounnikoff

Metta Kongphan-apirak

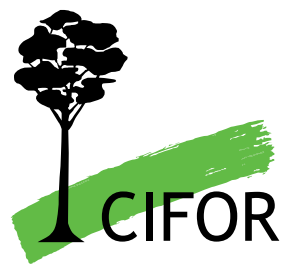



Working Paper No. 46

\section{Emerging REDD+}

A preliminary survey of demonstration and readiness activities

Sheila Wertz-Kanounnikoff

Metta Kongphan-apirak 
CIFOR Working Paper 46

(c) 2009 by the Center for International Forestry Research

All rights reserved

Printed in Denmark

CIFOR

J. CIFOR, Situ Gede

Bogor Barat 16115

Indonesia

$\mathrm{T}+62(251) 8622-622$

$F+62(251) 8622-100$

E cifor@cgiar.org

\section{www.cifor.cgiar.org}

The views expressed in this publication are those of the authors and not necessarily those of CIFOR.

This document has been produced with financial assistance from the Norwegian Agency for Development Cooperation and the David and Lucile Packard Foundation.

\section{Center for International Forestry Research}

CIFOR advances human wellbeing, environmental conservation, and equity by conducting research to inform policies and practices that affect forests in developing countries. CIFOR is one of 15 centres within the Consultative Group on International Agricultural Research. CIFOR's headquarters are in Bogor, Indonesia. It also has offices in Asia, Africa and South America. 


\section{Contents}

Acronyms

Acknowledgements viii

Abstract $\quad$ ix

1 Introduction 1

2 Emerging landscape of REDD+ activities 2

3 Preliminary analysis of REDD+ activities 6

3.1 Carbon effectiveness considerations 6

3.2 Cost-efficiency considerations $\quad 8$

$\begin{array}{lll}3.3 & \text { Equity and co-benefits considerations } & 10\end{array}$

4 Preliminary conclusion $\quad 13$

$\begin{array}{ll}\text { References } & 14\end{array}$

$\begin{array}{ll}\text { Annexes } & 16\end{array}$

1 Overview of all REDD+ activities 17

2 Overview of REDD+ demonstration activities 17

3 REDD+ countries: Forest context 18

4 REDD+ countries: Governance context 19

5 Survey results: REDD+ in Asia $\quad 20$

6 Survey results: REDD+ in Africa $\quad 28$

7 Survey results: REDD+ in Latin America $\quad 37$ 


\section{Acronyms}

$3 \mathrm{E}$

A/R

ACOFOP

$\mathrm{AD}$

AES

AEP

AfDB

ANAE

APRIL/RAPP

AUD

AusAID

BAU

BioCF

BMU

BMZ

BOS

CARE

CBNRM

CDM

CEPE

CI

CI-GCF

CIFOR

CIRAD

CKPP

$\mathrm{CO}_{2} \mathrm{e}$

COMIFAC

COP

DFID

DRC

ECOSUR

ERM
Effectiveness, efficiency, and equity, plus co-benefits

Afforestation and reforestation

Asociación de Comunidades Forestales de Petén (Guatemala)

Avoided deforestation

Applied Energy Services (now AES Corporation)

American Electric Power

African Development Bank

The National Association for Environmental Action (Madagascar)

Asia Pacific Resources International Holding/Riau Andalan Pulp and Paper

Australian dollar

Australian Agency for International Development

Business as usual

BioCarbon Fund

Bundesministerium für Umwelt, Naturschutz Und Reaktorsicherheit (Federal Ministry for the Environment, Nature Conservation and Nuclear Safety)

Bundesministerium Für Wirtschaftliche Zusammenarbeit (German Federal Ministry for Economic Development Cooperation)

Borneo Orangutan Survival Foundation

Cooperative for Assistance and Relief Everywhere

Community-based natural resource management

Clean development mechanism

Centre for Energy Policy and Economics

Conservation International

Conservation International-Global Conservation Fund

Center for International Forestry Research

Centre de Coopération Internationale en Recherche Agronomique pour le Développement (French Agricultural Research Centre for International Development)

Central Kalimantan Peatland Project

Carbon dioxide equivalent

Commission des Forêts d'Afrique Centrale (Central African

Forest Commission)

Conference of the Parties

Department for International Development (UK)

Democratic Republic of the Congo

El Colegio de la Frontera Sur (Mexico)

Environmental Resources Management 
ExSect $P$

FAN

FAO

FAS

FCPF

FFEM

FFI

FNMA

FONAFIFO

FORECA

FRA

FRM

FUNDECOR

FUPNAPIB

GER

GMES

GTZ

HSBC

I\&CV MRV

I\&CV Re-funds

ICI

ICRAF

IDB-MIF

INRENA

IFCA

IL\&Gov

IPAM

JICA

KFCP

KfW

MAR
Extra-sectoral policies to reduce the profitability of land conversion

Fundación Amigos de la Naturaleza (Friends of Nature Foundation, Bolivia)

Food and Agriculture Organization of the United Nations

Fundação Amazonas Sustentável (Amazonas Sustainable Foundation)

Forest Carbon Partnership Facility

Fonds français pour l'environnement mondial (French Global

Environment Fund)

Fauna and Flora International

Fundo Nacional do Meio Ambiente (National Environment Fund, Brazil)

Fondo Nacional de Financiamiento Forestal (National Forestry Financing

Fund, Costa Rica)

Forêts engagées pour le carbone (Committing forests as carbon reservoirs)

Forest Resources Assessment

Forest Resources Management (France)

Fundación para el Desarrollo de la Cordillera Volcánica Central (Foundation for the Development of the Central Volcanic Mountain Range)

Fundación Parque Nacional Pico Bonito (Pico Bonito National Park Foundation, Honduras)

Global Eco Rescue (Switzerland)

Global Monitoring for Environment and Security

Deutsche Gesellschaft für Technische Zusammenarbeit GmbH (German society for technical cooperation)

Hong Kong and Shanghai Banking Corporation

Institution and capacity building for MRV

Institution and capacity building for handling REDD funds

International Climate Initiative

International Centre for Research in Agroforestry

Inter-American Development Bank - Multilateral Investment Fund

Instituto Nacional de Recursos Naturales (National Institute of

Natural Resources)

Indonesia Forest Carbon Alliance

Improved governance and law enforcement

Instituto de Pesquisa Ambiental da Amazônia (Amazon Environmental

Research Institute)

Japan International Cooperation Agency

Kalimantan Forests and Climate Partnership

Kreditanstalt für Wiederaufbau (German Development Bank)

Monitoring, Assessment and Reporting 
BMI

MRV

$\mathrm{Mt}$

NGO

ODA

ODI

ONFI

ORAM

PA

PDD

PEAM

PES

PNG

PROFONANPE Fondo Nacional para Áreas Naturales Protegidas por el Estado (Peruvian Trust Fund for National Parks and Protected Areas)

RED

REDD

REDD+

Rehab

RIL

R-PIN

R-Plan

R-PP

RRI

R-strategy

SDC

SERNANP

SFM

STRI

tbd

TDERU

TNC

UNEP-WCMC

Banco Multisectorial de Inversiones (El Salvador)

Measurement, reporting and verification

Metric tonne

Nongovernmental organisation

Official development assistance

Overseas Development Institute

Office national des forêts

Organizacao Rural de Ajuda Mutua (Rural Association for Mutual Support) (Mozambique)

Protected area management

Project Design Document

Proyecto Especial Alto Mayo (Alto Mayo Special Project)

Payment for ecosystem services

Papua New Guinea

Reducing emissions from deforestation

Reducing emissions from deforestation and forest degradation

Reducing emissions from deforestation and forest degradation including carbon stock enhancement

Forest restoration or rehabilitation

Reduced impact logging

Readiness Plan Idea Notes

Readiness plan

Readiness preparation proposals

Rights and Resources Initiative

Preparation of national REDD strategy

Swiss Agency for Development and Cooperation

Servicio Nacional de Áreas Naturales Protegidas (National Natural Protected Areas Service)

Sustainable forest management

Smithsonian Tropical Research Institute

To be determined

Tropical Deforestation Emission Reduction Unit

The Nature Conservacy

United Nations Environmental Programme - World Conservation

Monitoring Centre

UNFCCC United Nations Framework Convention on Climate Change 
UN-REDD United Nations Collaborative Programme on Reducing Emissions from Deforestation and Forest Degradation in Developing Countries

WB The World Bank

WCS

Wildlife Conservation Society

WHRC

Woods Hole Research Center

WRI

World Resources Institute

WWF

World Wide Fund for Nature

ZSL

Zoological Society of London 


\section{Acknowledgements}

We thank Ken Chomitz, William D. Sunderlin, Elena Petkova and Erin Myers Madeira for valuable comments provided on an earlier draft. Any errors are those of the authors and should not be attributed to CIFOR. 


\section{Abstract}

This paper presents the results of a preliminary survey of emerging demonstration and readiness activities to reducing emissions from deforestation and forest degradation and carbon stock enhancement (REDD+) across Africa, Asia, and Latin America. The survey was conducted between November and December 2008, and the information collected was updated until May 2009. While the results of the survey offer a useful snapshot of the landscape of REDD+ activities, they do not capture all the dynamics associated with this rapidly evolving field. As the international debate on REDD+ continues, some projects surveyed may have changed their core objectives and activities, while others may never get off the ground. Another limitation of the survey is the ongoing lack of any clear definition of what constitutes a REDD+ demonstration activity. Despite these shortcomings, this survey offers insights on current trends to inform future REDD+ investments.

In total the survey found over 100 REDD+ activities: 44 demonstration activities, 65 readiness activities (including those by the Forest Carbon Partnerhship Facility and the UN-REDD Programme) and 12 activities where carbon is not an explicit goal. Indonesia has by far the most demonstration activities in the pipeline, making Asia the region with the largest number of REDD+ activities. Many projects (68\%) are still in the planning stage.

A preliminary assessment of incipient REDD+ investments shows the following. First, REDD+ initiatives, especially demonstration activities, tend to target countries where deforestation or the risk of deforestation is significant, which suggests realised carbon effectiveness considerations. Second, poor governance contexts do not discourage REDD+ investments, although cost-efficiency considerations may suggest otherwise. Third, although there is scope for natural equity and co-benefits, there is also a risk of trade-offs between carbon effectiveness and cobenefits. Dry forests - where many rural poor live and where there are high levels of biodiversity - tend to be carbon poor and, thus, feature far less in REDD+ demonstration activities than humid forests.

Balancing trade-offs between cost-effectiveness and co-benefit considerations will likely become a central challenge for REDD+ policies and activities. Spatially explicit, high-resolution, environmental and socioeconomic data can offer new scope for REDD+ investments to enhance carbon goals while securing REDD+ co-benefits. Policy makers, donors, and other investors in REDD+ and/or REDD+ co-benefits could assemble such data to enhance their investment choices, monitor their outcomes, and thus provide valuable lessons to inform the national and global REDD+ architecture.

Although performance-based payments analogous to payments for environmental services (PES) are core features of the REDD+ idea, the survey further shows that REDD+ policies will require more than PES-type REDD+ schemes. Investments in improved governance and broader policy reforms are equally important to address the root causes of forest emissions. Finding the right policy mix in different country contexts is an important challenge ahead. 



\section{Introduction}

$\mathrm{T}$ he international community now recognises reducing emissions from deforestation and forest degradation and carbon stock enhancement (REDD+) as a critical component of national and international strategies for mitigating global climate change. Following the call of the Bali Action Plan, agreed at the 13th Conference of the Parties (COP 13) to the United Framework Convention on Climate Change (UNFCCC) in Bali in December 2007, numerous REDD+ demonstration activities got underway on the ground, supported by NGOs, the private sector, bilateral donors, and multilateral agencies.

REDD+ demonstration activities focus on experimenting with mechanisms that can reduce forest emissions in preparation for the era of conditional carbon deals. To date there is no agreed definition of 'demonstration activities' and activities range from site-specific projects to larger-scale activities that cover a substantial portion of a province. Key activities include the promotion of more sustainable forest management practices (e.g. reduced impact logging), forest conservation combined with incentive payment schemes, and monitoring systems that measure the change in carbon stocks and fluxes. Reliable carbon monitoring systems are a key element of these activities. Carbon deals are output-based, meaning that carbon payments are only made for certified emissions reductions. Following promising experiences with payments for environmental services schemes, conditional REDD+ payments are regarded as an incentive - financial or in-kind - to promote behavioral changes by land managers.

At the same time, many countries are in the process of developing national REDD+ strategies. In principle, REDD+ strategies are the first step in the implementation of REDD+ policies and measures, and can be compared to a roadmap to move from the situation today towards a desired future scenario of reduced forest emissions (Dutschke et al. 2008). ${ }^{2}$
One major incentive for countries to design REDD+ strategy development plans has been the prospect of accessing funds from the World Bank-administered Forest Carbon Partnership Facility (FCPF) and, more recently, from the UN-REDD Programme, to finance REDD+ readiness activities.

REDD+ readiness activities refer to the measures and mechanisms that are necessary to establish an enabling framework for REDD+ deals. These can include land tenure reforms, effective enforcement of land use laws and regulations, and the establishment of systems to reliably monitor, report, and verify forest emissions.

In the context of these developments, this paper takes stock, and conducts a preliminary assessment, of REDD+ demonstration and readiness activities. It examines emerging trends in evolving REDD+ activities with respect to their effectiveness, efficiency, and implications for equity and co-benefits (the 3Es). The aim is to provide early feedback on REDD+ demonstration and readiness activities to host countries, donors, and project developers.

A note of caution is necessary. Since the REDD+ landscape is evolving rapidly, the survey only takes a snapshot of emerging activities. Also, because the survey relies primarily on secondary information from the public domain (internet, brochures, project documents) there may be inconsistencies between what is described in the secondary information and the actual state and nature of activities. The survey should thus be seen more as a documentation of trends in 'marketed activities' rather than as a description of actual activities on the ground.

This paper is organised as follows. Section 2 gives an overview of the emerging landscape of REDD+ activities. Section 3 analyses the activities according to effectiveness, efficiency and equity plus co-benefit considerations. Section 4 presents preliminary conclusions. 


\section{Emerging landscape of REDD+ activity}

To map the emerging landscape of REDD+ activities and, since REDD+ activities are not always described as such, we conducted a survey of all activities that focus on reducing forest emissions and enhancing forest carbon stocks (e.g. forest restoration) (see Annexes 5-7). The survey was conducted during November and December 2008 and continuously updated until May 2009. It covers Africa, Asia, and Latin America.

We distinguish three types of REDD+ activities:

- Demonstration activities. In the absence of a clear definition, we use the term 'demonstration activity' to refer to activities where carbon is the explicit objective. Given the ongoing debate over the role of forest plantations in REDD+ (see Box 1), we excluded carbon forestry projects that had afforestation or reforestation as a main activity.

- Readiness activities. We use this term for all activities that are designed to create an enabling framework for REDD+ deals. These include capacity building, implementation of monitoring systems, and development of REDD+ strategies. All activities under the UN-REDD Programme and the FCPF Window II (Readiness Fund) are classified as readiness activities.

- Activities without explicit carbon goals. We use this term to refer to projects where carbon is not the explicit objective. For example, the ProAmbiente Program in Brazil aims at implementing a payment for ecosystem services (PES) scheme for enhanced ecosystem management, but it is not intended primarily for sequestering forest carbon.

As of May 2009, we found 44 REDD+ demonstration activities, 65 REDD+ readiness activities - of which 37 refer to readiness plan idea note (R-PIN) developments - and 12 activities without explicit carbon objectives. In the survey we excluded readiness plan (R-Plan, now called Readiness Preparation Proposals, R-PP) activities (Indonesia, Guyana, Panama). This avoids double counting REDD+ strategy development activities, as R-Plans are the successors of R-PINs. However, Indonesia is an exception, as here the R-PIN exercise has been replaced by equivalent studies developed within the scope of the Indonesia Forest Carbon Alliance (IFCA) process.

The forest transition curve is an empirical model of forest cover change over time in response to economic development. The differences in REDD+ challenges are also reflected in this pattern, starting from the need to reduce forest degradation and deforestation in the early stages of the forest transition curve (Stage 1). The curve falls steeply during the early transition stage, and reducing deforestation is needed to secure climate benefits (Stage 2). In the later stage, when forest cover tends to regrow, climate benefits mainly arise from

\section{Box 1. Changing definitions: RED, REDD and REDD+}

When emissions from forestry reclaimed the attention of the climate negotiations in 2005, the discussions initially focused only on 'avoided deforestation', i.e. 'AD' or 'RED' for short. With growing recognition that forest degradation is inseparable from reduction of forest emissions, 'avoided degradation' - or the second 'D' in 'REDD' - was officially endorsed at the UNFCCC COP-13 in Bali in 2007. As the debate continued, it was further recognised that climate benefits can arise not only from avoiding negative changes (deforestation, degradation), but also from enhancing positive changes, in the form of forest conservation and restoration (Angelsen and Wertz-Kanounnikoff 2008). The recognition of the latter was expressed with a ' + ', which became official vocabulary at COP-14 in Poznań in 2008. The range of forest management challenges covered by REDD+ can be illustrated by the forest transition curve (Figure 1).

One open question with REDD+ concerns the role of afforestation and reforestation (A/R). Eligible in the Clean Development Mechanism (CDM) - and hence already part of the international toolbox to mitigate climate change - the question is whether and how A/R will become part of REDD+. Several environmental NGOs oppose including forest plantations into a global REDD+ scheme because of the risk of promoting plantation forestry at the expense of biodiversity conservation (e.g. Greenpeace 2009). However, others argue that forest plantations need to be part of REDD+ to allow for greater consistency in landscape planning and, ultimately, to reduce forest emissions (e.g. proposals by Indonesia, India and China, see Parker et al. 2009). The discussion is still ongoing. 


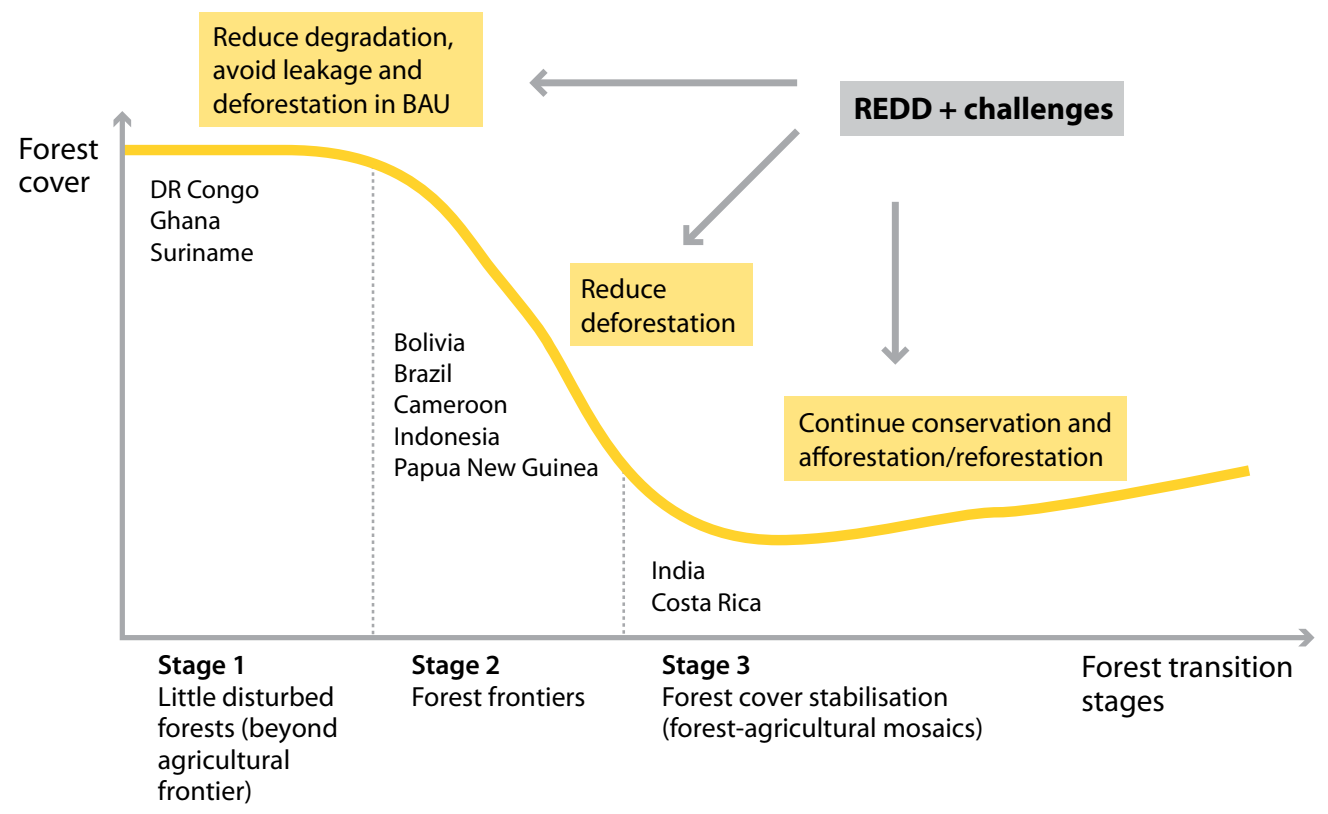

Figure 1. Forest transition curve and associated REDD+ challenges

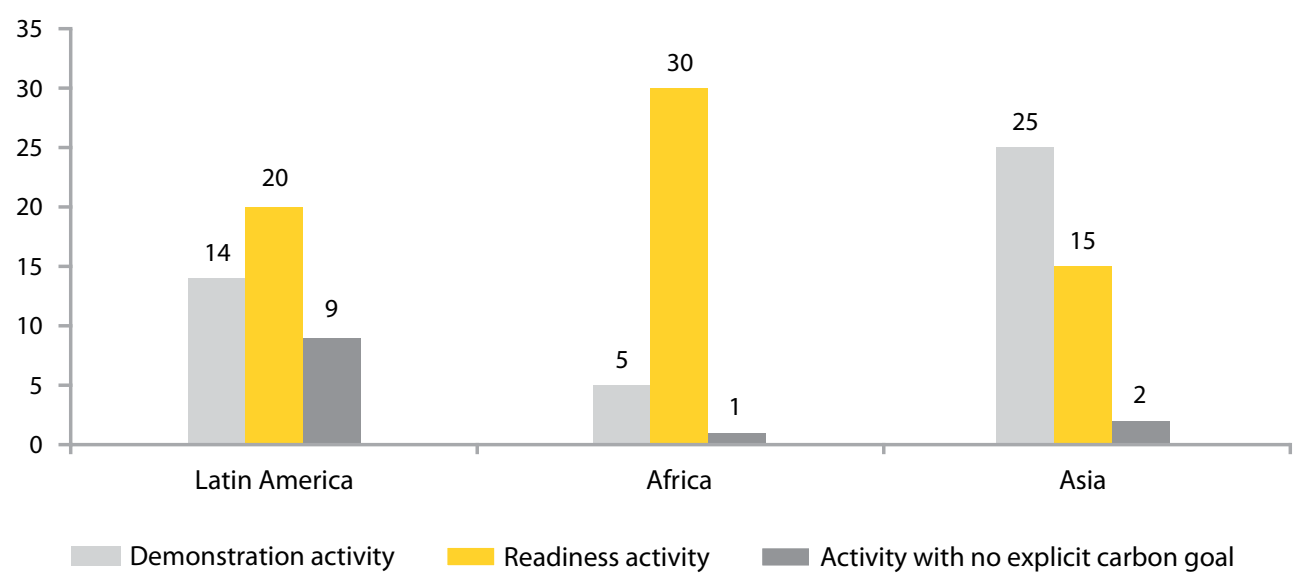

Figure 2. Regional distribution of demonstration and readiness activities

continued conservation, carbon stock enhancement and afforestation and reforestation (Stage 3).

The survey results show clear regional variations in the distribution of REDD+ activities (Figure 2).

Demonstration activities are currently concentrated in Asia, notably Indonesia, while readiness activities are primarily clustered in Central Africa. Latin America has an intermediate number of demonstration and readiness activities.

However, most REDD+ activities are still at the beginning or planning stages (Figure 3). In Latin America more REDD+ demonstration activities are already underway compared to those in Africa and Asia.
'Planned activities' refer to all those that are reported to be in the planning phase and where no implementation has started. 'Ongoing' means project implementation has started. In total we found that 14 REDD+ demonstration activities are currently underway, while most -30 projects - are still in the planning phase. The picture is similar for REDD+ readiness activities with 5 currently ongoing and 60 planned. Although most countries have REDD+ activities that are still in the planning stage, some countries have already developed policies, mainly forest management plans, that will facilitate the implementation of REDD+ activities (WHRC 2009). 
The size of REDD+ demonstration activities varies greatly. For those projects for which information was available, we classified them into small $(<50000 \mathrm{ha})$, medium (50 000-500 $000 \mathrm{ha})$ and large (>500 000 ha) and counted the number of projects per size class
(Figure 4). Most of the small projects are found in Latin America, while the sum of medium to large-scale ones are primarily found in Asia, where projects can extend to almost an entire province, such as in the case of Berau in Indonesia.

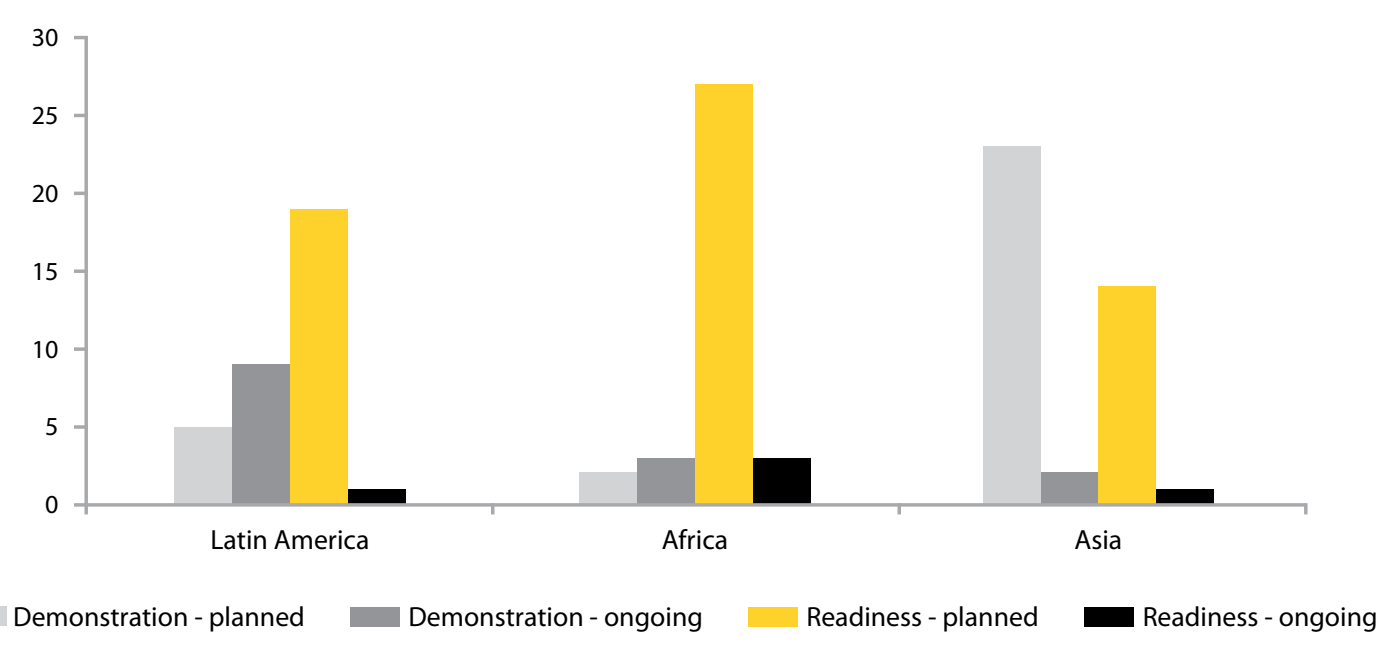

Figure 3. Status of REDD+ activities

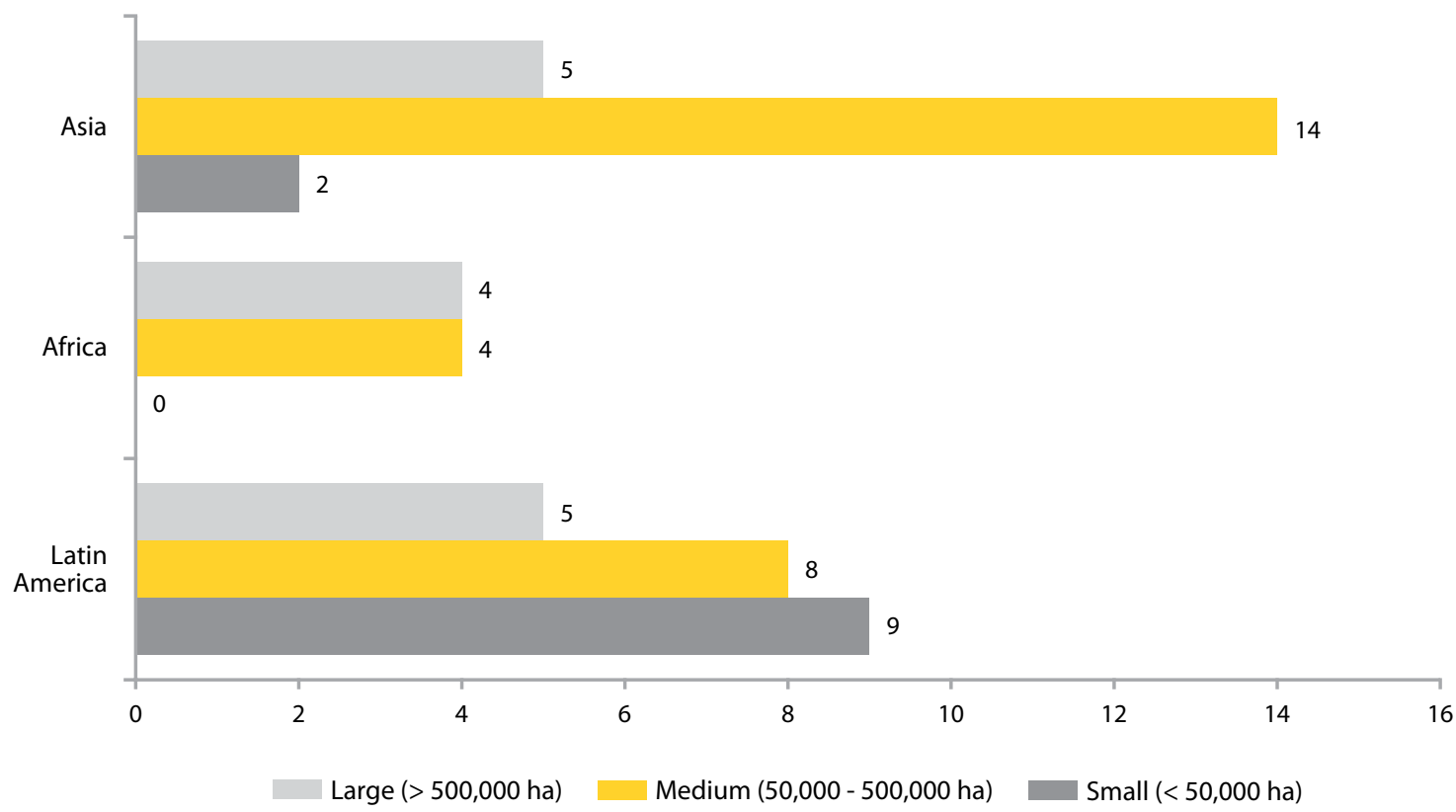

Figure 4. Size of REDD+ demonstration activities 


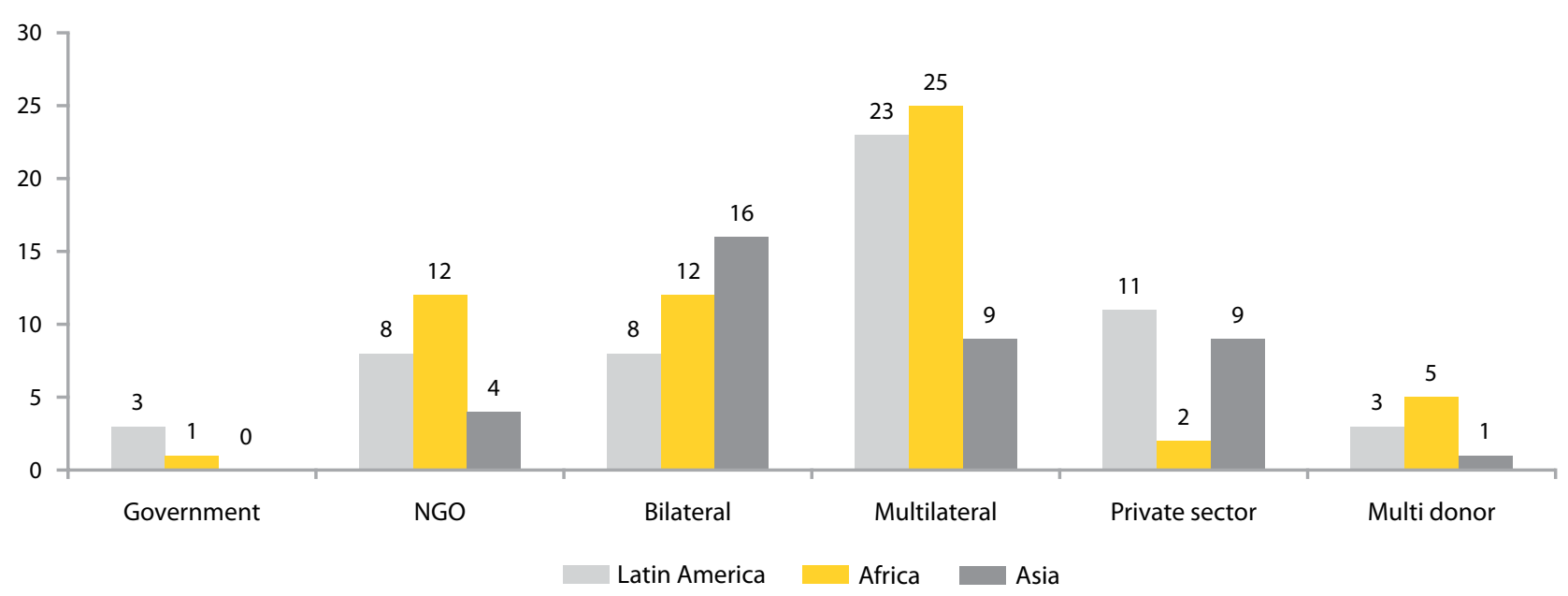

\section{Figure 5. Financing sources of REDD+ activities by region}

Government financing refers to activities that are financed by the developing country government, such as in Brazil and El Salvador.

Our survey found that most REDD+ demonstration and readiness activities, especially in Africa, are financed with international public funds, i.e. official development assistance (ODA). Specifically, bilateral, multilateral and government sources fund 65\%, 64\%, and $61 \%$ of the REDD+ activities, respectively, in Africa, Asia and Latin America. The private sector - although financing less activities than the public sector - is still an important financier of REDD+ activities, especially in Latin America and Asia. NGOs are comparatively more involved in financing REDD+ activities in Africa. Non-public finance (private sector, NGO) still constitutes only a small proportion of overall REDD+ financing. Note that Figure 5 shows only the sources of finance for projects, not the amount of financial support. It is therefore not possible to determine the sources that provide the most funding in absolute terms. The chart merely shows the number of projects receiving financing for REDD+ activities from the different sources. 


\section{Preliminary analysis of REDD+ activities}

A thorough analysis of REDD+ activities is currently challenged for two reasons. First, not much information is available in the public domain - in part because many activities have only just got under way and, also, because project developers probably fear competitors or criticism that could undermine the success of their projects. Second, the sector is highly dynamic. New activities are rapidly emerging while others exist only on paper and are not implemented.

Despite these challenges, we considered it worthwhile to take a snapshot of the rapidly evolving landscape of REDD+ demonstration and readiness activities. Our objective was to identify emerging trends and to provide feedback to policy makers and practitioners on the characteristics of initial REDD+ investments. To differentiate and analyse the projects, we used the $3 \mathrm{E}$ criteria - carbon effectiveness, cost-efficiency, and equity plus co-benefits (Angelsen and WertzKanounnikoff 2008).

\subsection{Carbon effectiveness considerations}

REDD + was originally conceived as a way to secure climate benefits by providing financial incentives for reducing forest emissions. To maximise such climate benefits, the investments (financial incentives) targeted the drivers of forest emissions, in particular in areas where deforestation or the risk of deforestation is currently high - areas on the slope (high deforestation) or at the top of the slope (risk of high deforestation) on the forest transition curve (Figure 1). These areas are assumed to be where investments can really make a difference, compared to the business-as-usual scenario (without carbon finance), i.e. they are areas with the highest additionality, the central criterion for effectiveness.

To test this hypothesis, we cross-classified REDD+ countries by level of deforestation (high/low) and by forest cover (high/low) (Table 1 and Figure 6). As there are no agreed definitions of high/low forest cover or high/low deforestation rates, we chose to use a $0.5 \%$ deforestation rate as the cut-off point between high and low deforestation (although the average in developing countries is about $0.3 \%$ ). For the forest cover we set $40 \%$ as the cut-off point between high and low forest cover. ${ }^{3}$ We used FAO deforestation data as it provides full coverage of tropical countries, while acknowledging data quality concerns (e.g. Kaimowitz and Angelsen 1999) and the emergence of more accurate data for humid tropical forests (see Hansen et al. 2008). As most REDD+ demonstration activities are located in countries of high deforestation, and especially in countries of high deforestation and high forest cover - on the upper part of the forest transition slope - we find some evidence supporting the hypothesis that investments are targeting the drivers of forest emissions.

Table 1. Countries classified by forest cover context

\begin{tabular}{|c|c|c|}
\hline & $\begin{array}{l}\text { Low deforestation rates } \\
\qquad(<0.5 \%)\end{array}$ & $\begin{array}{l}\text { High deforestation rates } \\
\qquad(>0.5 \%)\end{array}$ \\
\hline $\begin{array}{l}\text { High forest cover } \\
(>40 \%)\end{array}$ & $\begin{array}{l}\text { Belize, Colombia, Costa Rica, DR Congo, } \\
\text { Guyana, Panama, Peru, Republic of Congo, } \\
\text { Suriname }\end{array}$ & $\begin{array}{l}\text { Bolivia, Brazil, Cambodia, Cameroon, } \\
\text { Equatorial Guinea, Honduras, Indonesia, } \\
\text { Lao PDR, Nicaragua, Paraguay, Papua New } \\
\text { Guinea, Zambia }\end{array}$ \\
\hline $\begin{array}{l}\text { Low forest cover } \\
(<40 \%)\end{array}$ & $\begin{array}{l}\text { Argentina, Chile, Central African Republic, } \\
\text { Kenya, Madagascar, Mexico, Mozambique, } \\
\text { Thailand, Vanuatu, Vietnam }\end{array}$ & $\begin{array}{l}\text { Ecuador, El Salvador, Ethiopia, Ghana, } \\
\text { Guatemala, Guinea, Liberia, Nepal, } \\
\text { Tanzania, Uganda }\end{array}$ \\
\hline
\end{tabular}

Source: FAO 2005, FAO data for Gabon not available 
The picture is less clear in the case of REDD+ readiness activities. Although most readiness activities are concentrated in countries of high deforestation/high forest cover where additionality is highest, a similar proportion of activities can be found in other forest cover contexts where additionality is far lower. This pattern of channeling investments to countries at early or advanced stages of the forest transition curve (Stages 1 and 3 in Figure 1) as well as to high deforestation/ high forest cover areas - may be a response to early criticisms that REDD+ excluded countries with low deforestation rates (e.g. da Fonseca et al. 2007).

The regional distribution of efforts by the UN-REDD Programme and the FCPF also reflects differences in targeting for high carbon effectiveness. Most UNREDD efforts focus on areas of high additionality (high deforestation/high forest cover), but FCPF efforts are distributed more evenly across all forest contexts (Table 2).

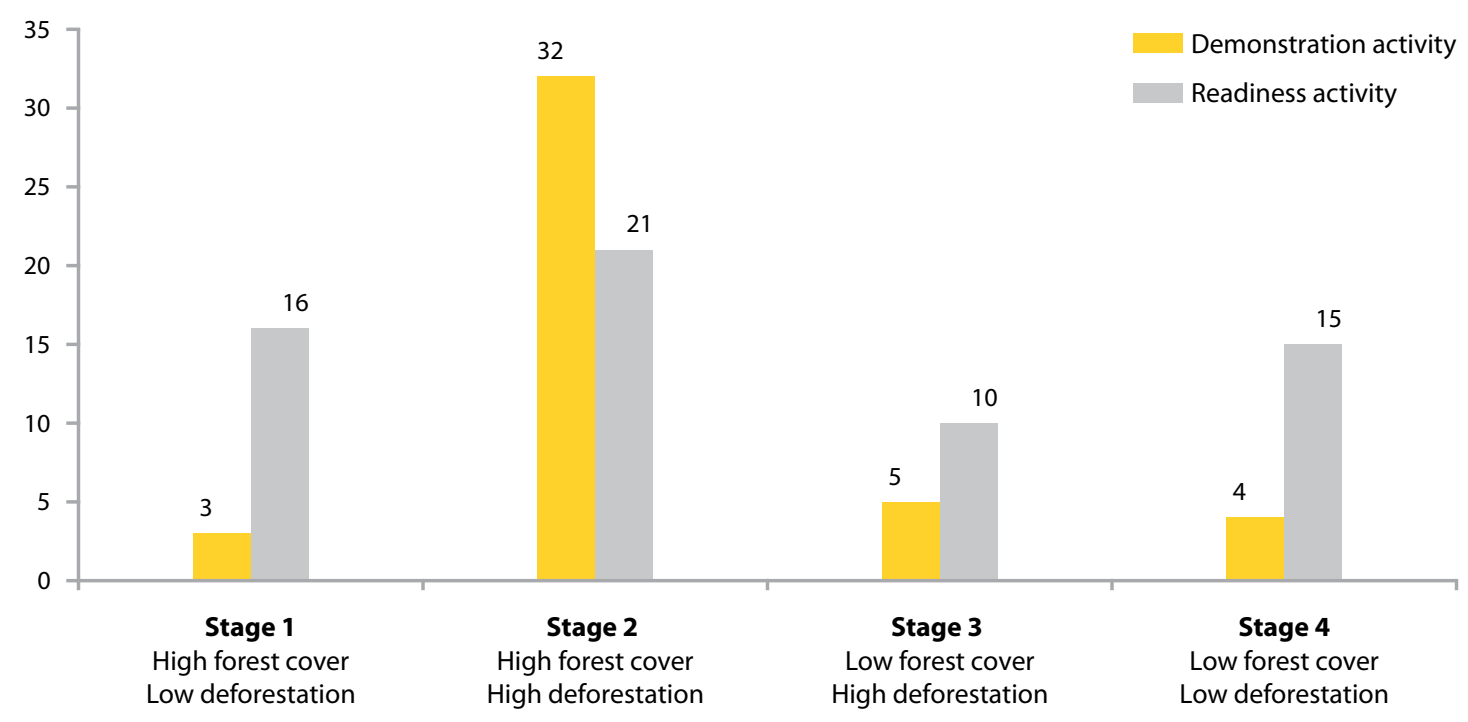

Figure 6. REDD+ demonstration and readiness activities by countries of high/low forest cover (cut-off point $\mathbf{4 0} \%$ ) and high/low deforestation rates (cut-off point $\mathbf{0 . 5 \%}$

Source: FAO 2005

Table 2. Distribution of FCPF and UN-REDD efforts by forest contexts

\begin{tabular}{|c|c|c|}
\hline & FCPF & UN-REDD \\
\hline $\begin{array}{l}\text { Low deforestation/ } \\
\text { high forest cover }\end{array}$ & $\begin{array}{l}\text { Colombia, Costa Rica, DR Congo, } \\
\text { Equatorial Guinea, Republic of Congo, } \\
\text { Guyana, Panama, Peru, Suriname } \\
\text { (9 countries) }\end{array}$ & $\begin{array}{l}\text { DR Congo, Panama } \\
(2 \text { countries })\end{array}$ \\
\hline $\begin{array}{l}\text { High deforestation/ } \\
\text { high forest cover }\end{array}$ & $\begin{array}{l}\text { Bolivia, Cambodia, Cameroon, Honduras, } \\
\text { Indonesia, Lao PDR, PNG, Nicaragua, } \\
\text { Paraguay } \\
\text { (9 countries) }\end{array}$ & $\begin{array}{l}\text { Bolivia, Indonesia, Paraguay, Papua New } \\
\text { Guinea, Zambia } \\
\text { (5 countries) }\end{array}$ \\
\hline $\begin{array}{l}\text { High deforestation/ } \\
\text { low forest cover }\end{array}$ & $\begin{array}{l}\text { El Salvador, Ethiopia, Ghana, Guatemala, } \\
\text { Liberia, Nepal, Tanzania, Uganda } \\
\text { (8 countries) }\end{array}$ & Guatemala \\
\hline $\begin{array}{l}\text { Low deforestation/ } \\
\text { low forest cover }\end{array}$ & $\begin{array}{l}\text { Argentina, Central African Republic, Chile, } \\
\text { Kenya, Thailand, Madagascar, Mexico, } \\
\text { Mozambique, Vanuatu, Vietnam } \\
\text { (10 countries) }\end{array}$ & Vietnam \\
\hline
\end{tabular}


However, two caveats apply. First, national-level aggregated data, as used here, hide important subnational variations in deforestation rates. Deforestation rates are defined by the denominator, which can give entirely different results across spatial scales. For example, deforestation rates differ substantially if one considers Brazil as a whole, the Brazilian State of Mato Grosso, or the forest frontier in Mato Grosso. In addition to the data quality concerns mentioned with respect to the FAO data, fine resolution data (and denominators) are needed to give more accurate insights into deforestation rates and the carbon effectiveness of REDD + investments. Second, deforestation rates - the area of forest cover lost - only serve as proxy indicators for climate benefits. The carbon benefits are ultimately defined by the carbon content of the forest biome that is being deforested (or conserved). To truly maximise carbon benefits, REDD+ investors would need to use high resolution data - for changes in forest cover and carbon density - to target areas with both high deforestation and high carbon density.

\subsection{Cost-efficiency considerations}

One widespread vision for REDD+ is to have a scheme of performance payments comparable to the payments for environmental services (PES) ${ }^{4}$ schemes (e.g. Angelsen and Wertz-Kanounnikoff 2008). For REDD+ arrangements to function in a similar way to PES, certain preconditions must be met. Among these are strong institutions and good governance (Wunder 2008; Bond et al. 2009). The absence of strong institutions can make PES-type deals prohibitively

\section{Demonstration activities}

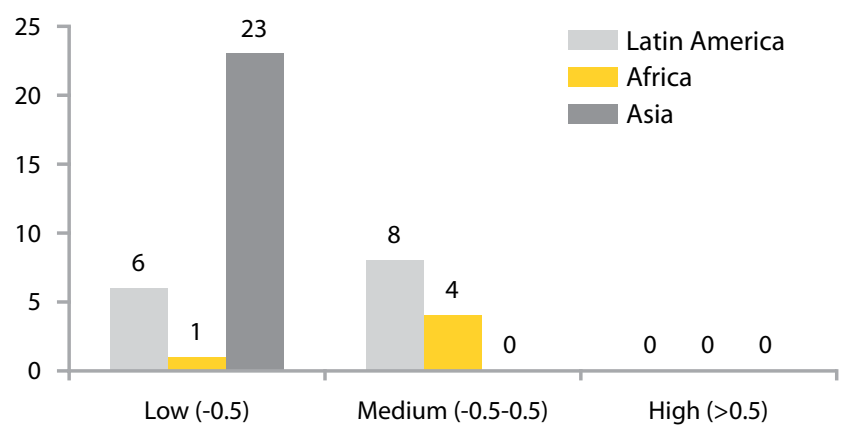

expensive because of the transaction costs associated with negotiating and enforcing (monitoring) the deals.

To show the cost efficiency of REDD+ investments, we examine the governance characteristics of the places where REDD+ activities are taking place. Specifically, we map REDD+ investments, i.e. demonstration and readiness activities, against levels of governance using two types of indicator - national governance indices and information on land tenure.

Mapping REDD+ activities against levels of national governance shows that both REDD+ demonstration and readiness activities are concentrated in countries with low governance levels (see Figure 7). The governance index we used is the mean of two variables, measuring law enforcement (rule of law) and perception of corruption (control of corruption) ${ }^{5}$ as used for the World Bank Governance Indicators (Kaufmann et al. 2008). We classify countries according to their governance index: low (<-0.5), medium $(-0.5$ to 0.5$)$ and high $(>0.5)$. The bars in Figure 7 show the number of REDD+ demonstration and readiness activities per region identified by the survey. None of the countries with REDD+ activities (except one in Latin America) have a high governance level score. Countries with low governance scores have a large share of REDD+ activities.

This result is counter-intuitive as one would expect REDD+ investments to favor high governance environments. One possible explanation is that current REDD+ finance originates primarily from public funds

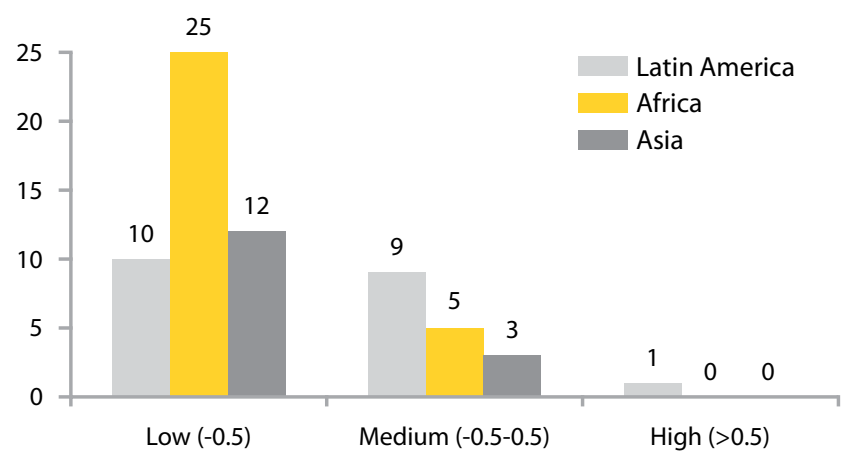

Figure 7. REDD+ activities by levels of governance

4 Payments for environmental services can be defined as voluntary transactions where a well-defined environmental service (or a land use likely to secure that service) is being bought by at least one environmental service buyer from at least one environmental service provider if and only if the environmental service provider secures the environmental service provision (Wunder 2005).

5 Rule of law means 'the extent to which agents have confidence in, and abide by, the rules of society and, in particular, the quality of contract enforcement, the police, and the courts, as well as the likelihood of crime and violence'. Control of corruption means 'the extent to which public power is exercised for private gain, including both petty and grand forms of corruption, as well as "capture" of the state by elites and private interests' (Kaufmann et al. 2008). 
(ODA, see Figure 5), for which development objectives count for more than they would for private investors. This leaning towards low governance environments offers opportunities to reduce current barriers to carbon finance for REDD+ by investing in measures to enhance governance (e.g. tenure reform, command-and-control). At the same time, governance investments or other non-PES policies can directly result in reduced emissions and, hence, function as direct instruments for REDD+. Especially in low governance contexts, policy makers, donors and other REDD+ investors could pay explicit attention to the potential of governance or other policy investments (e.g. enhanced enforcement of tenure rules and responsibilities) as a more cost-effective option than PES-type deals to directly reduce forest emissions.

Additionally, the World Bank governance indicators probably overestimate the actual governance environments for REDD+. In many countries, governance is weaker in forest frontier areas than in other areas (Kishor and Damania 2007), especially in forest frontiers where deforestation activity is concentrated. A more accurate assessment of the governance conditions relevant for PES-type REDD+ deals requires specific indicators, such as those currently developed by the World Resources Institute (WRI). ${ }^{6}$
In particular, property rights play a critical role in the governance of forests. This is because current thinking is that clear and secure forest tenure and ownership by individuals or communities encourages investment. Resource conflict is less likely to occur, and the people and communities have more power to bargain than those who live and use resources classified as state forests (Sunderlin et al. 2008). However, the reality is different. According to a survey by the Rights and Resources Initiative (RRI), 77\% of the global forest area is under government control and $12 \%$ is under private control (individuals and firms), while only $4 \%$ and $7 \%$ of the global forest area is designed for, used, and owned by communities and indigenous people respectively (Sunderlin et al. 2008). Although de jure land rights are not a precondition for PES provided that de facto control over land exists, this will be different for REDD+ performance payments where formal rights to carbon will likely play an important role. This suggests that there is little room for PES-type REDD+ deals that provide direct incentives to local forest stewards who have control over their lands (private or community users) unless further devolution of rights occurs.

Yet governance levels are not the only factor in the costeffectiveness of REDD+ investments. The opportunity costs of forest conservation matter too. A spatially explicit analysis of opportunity costs can help determine the level

Table 3. REDD+ activity and opportunity costs of forest conservation

\begin{tabular}{|c|c|c|c|c|c|}
\hline Country & $\begin{array}{l}\text { Opportunity costs } \\
\text { (US \$) }\end{array}$ & $\begin{array}{c}\text { Mean } \\
\text { opportunity } \\
\text { costs/ha (US \$) }\end{array}$ & $\begin{array}{l}\text { Deforestation } \\
\text { rates [ha/year] } \\
\text { (FAO 2005) }\end{array}$ & $\begin{array}{c}\text { REDD+ } \\
\text { readiness } \\
\text { activities }\end{array}$ & $\begin{array}{c}\text { REDD+ } \\
\text { demonstration } \\
\text { activities }\end{array}$ \\
\hline Brazil & $\begin{array}{r}1977803000 \\
(637 / \mathrm{ha})\end{array}$ & 637 & -0.6 & 0 & 5 \\
\hline Cameroon & $\begin{array}{r}204662000 \\
(930 / \mathrm{ha})\end{array}$ & 930 & -1 & 4 & 1 \\
\hline DRC & $\begin{array}{r}296760000 \\
(930 / \mathrm{ha})\end{array}$ & 930 & -0.2 & 4 & 0 \\
\hline Ghana & $\begin{array}{l}125366000 \\
(1090 / \mathrm{ha})\end{array}$ & 1090 & -2 & 1 & 0 \\
\hline Bolivia & $\begin{array}{rl}363560 & 000 \\
& (1346 / \mathrm{ha})\end{array}$ & - & -0.5 & 2 & 1 \\
\hline Indonesia & $\begin{array}{r}2976751000 \\
(1590 / \mathrm{ha})\end{array}$ & - & -2 & 4 & 24 \\
\hline Malaysia & $\begin{aligned} 247961000 \\
(1771 / \mathrm{ha})\end{aligned}$ & - & & 0 & 0 \\
\hline PNG & $\begin{array}{rl}381473 & 000 \\
& (2744 / \mathrm{ha})\end{array}$ & - & -0.5 & 3 & 0 \\
\hline
\end{tabular}

Source: Grieg-Gran 2008. Countries are ranked by mean opportunity cost per hectare 
REDD+ demonstration activity by levels of biodiversity

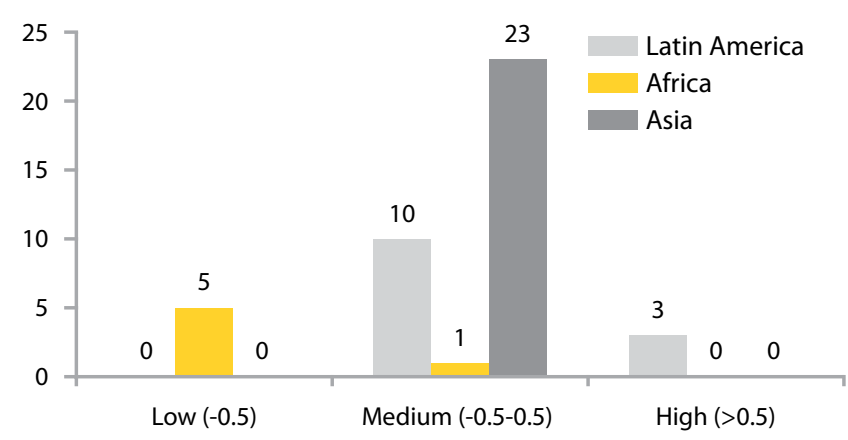

Figure 8. REDD+ activity by level of biodiversity

of compensation needed to induce changes in land use behavior. For example, Table 3 illustrates the range of absolute and relative (mean per hectare) opportunity costs in the eight major deforesting countries, Brazil, Bolivia, Cameroon, DRC, Ghana, Indonesia, Malaysia and PNG (Grieg-Gran 2008). For each country, the table also gives the number of REDD+ activities found by the survey. One can argue that, at a minimum, there should be compensation for the opportunity costs in order to avoid deforestation in these countries (see Eliasch 2008). However, it is important to recall that these cost values present national mean values, which hide sub-national variation. A more accurate assessment of the cost-efficiency aspects of REDD+ requires a high-resolution assessment of the opportunity costs of forest conservation, including the costs of activities to avoid forest degradation. Therefore, in order to make a decision on where to invest and how to design REDD+, opportunity costs need to be calculated for different locations.

\subsection{Equity and co-benefits considerations}

Many forests not only contain large amounts of carbon, but also provide other important non-carbon benefits (Brown et al. 2008). These include environmental services, such as water and biodiversity conservation, that are important for human well being. At the same time, forests are an important source of livelihoods for many people around the world. The potential for REDD + to keep forests standing, and therefore protect these livelihoods, is gaining increasing attention.

Biodiversity conservation is a natural co-benefit of REDD+ despite some divergence in targeting for the highest pay-off of forest carbon and biodiversity geographically. Cross-tabulating REDD+ activities against national biodiversity indices (Figure 8 ) shows that $90 \%$ of the demonstration activities are located in areas of medium to high biodiversity, especially in Asia. Similarly, 96\% of the readiness activities
REDD+ readiness activity by levels of biodiversity

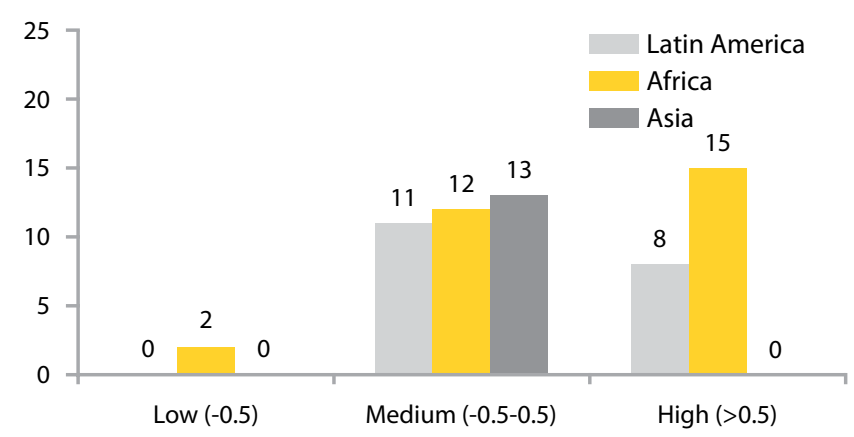

occur in countries with at least medium levels of biodiversity, while $37 \%$ are in areas with high levels of biodiversity. For this tabulation, we used the biodiversity index derived by Ebeling and Yasue (2008) from environmental sustainability indicators (Esty et al. 2005). These consist of a variable combining the proportion of threatened species, proportion of countries' eco-regions under threat, and overall levels of endemism. The countries are classified according to low $(<40 \%)$, medium (40-60\%) and high $(>60 \%)$ levels of biodiversity.

REDD+ can offer important synergies for biodiversity and carbon conservation. A first step for the more accurate targeting of REDD+ activities is the use of disaggregated spatial data on biodiversity and carbon density as illustrated by the UNEP-World Conservation Monitoring Centre (WCMC) demonstration (Kapos et al. 2008). To maximise biodiversity co-benefits from REDD+, more detailed cost-benefit mapping is needed. Carbon density values and levels of biodiversity (the benefits) should be mapped against the opportunity costs of conservation (the costs).

We examined national-level data and found that REDD+ activities, especially demonstration activities, are concentrated in humid forests rather than in dry forest areas (Figure 9). Readiness activities are more equally distributed between humid, semi humid, and dry forest areas. Assessing REDD+ activities more accurately by biome would require spatial analysis of geo referenced REDD+ activities overlaid with fine resolution data on forest types. For the cross-tabulation in this paper we used coarse resolution data of the predominant forest type in each country, as this data is comparable across countries.

Leaving aside inaccuracies related to the use of nationallevel data, one explanation for the neglect of dry forest areas is that these forests are generally poorer in carbon than humid forests (Ebeling and Yasue 2008). However, this is arguable. Dry forests cover 


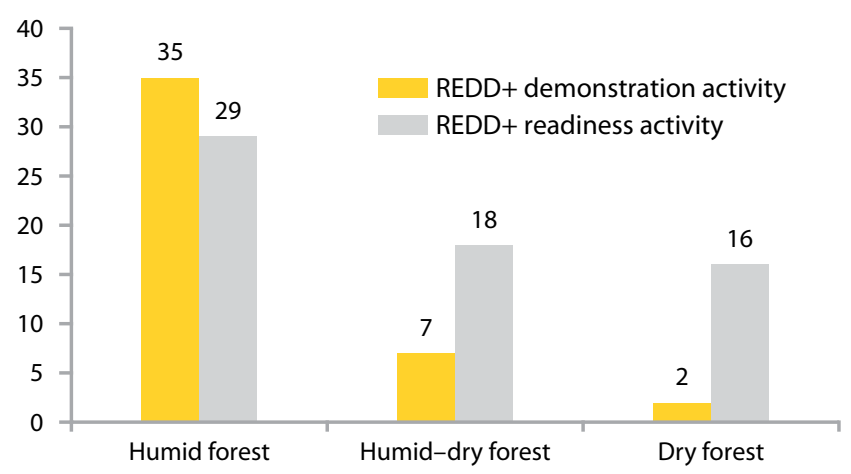

\section{Figure 9. REDD+ activities by forest biomes}

Source: WWF 2001, cited in Olson et al. 2001

greater areas than humid forests in the tropics and are typically more degraded, making them key target areas for terrestrial carbon storage, recovery, and 'avoided' deforestation projects (Glenday 2008). In addition, dry forests offer a particularly promising opportunity for targeting REDD+ co-benefits; they tend to have higher population densities than humid forests and mainly poor people (Sunderlin et al. 2008), along with high levels of biodiversity (Myers et al. 2000).

The location-specific assessments of the costs (opportunity costs, transaction costs) and benefits (carbon, biodiversity, poverty reduction) can help maximise REDD+ co-benefits by targeting interventions at high-return areas.

To examine the potential for social REDD+ co-benefits, we classified the surveyed demonstration activities according to their stated objectives. Figure 10 shows the types of objectives stated by REDD+ demonstration activities. To capture the full range of activities, we allowed for multiple statements, i.e. if a project reported its activities to be PES, sustainable forest management (SFM) and community-based natural resource management (CBNRM), we listed all of them. Specifically, our survey found that:

- Forest rehabilitation is among the most frequently listed project activities, especially in Asia (notably Indonesia) and to a lesser, though still significant, extent in Latin America.

- Forest conservation is also mentioned frequently, especially in Latin America.

- Community-based natural resource management is often cited in projects conducted in Asia, while absent from projects in Africa.

- Sustainable forest management seems particularly common in Asia.

- Payments for environmental services (PES), a core idea of REDD+, is only mentioned in Latin American activities.

The implications for REDD+ co-benefits are as follows. Since most activities are of an 'activity enhancing' nature (as opposed to 'activity reducing' as in the case of pure forest protection), positive social co-benefits seem likely especially where community-based forest management is a significant project objective. However, the ultimate degree and nature of co-benefits depends on the design of the REDD+ scheme and how benefits and costs are distributed across the actors involved. In addition, to further secure and enhance REDD+ co-benefits, supplementary finance (e.g. international biodiversity finance, official development assistance) can help direct REDD+ investments towards areas and countries that are priorities for conservation and development.

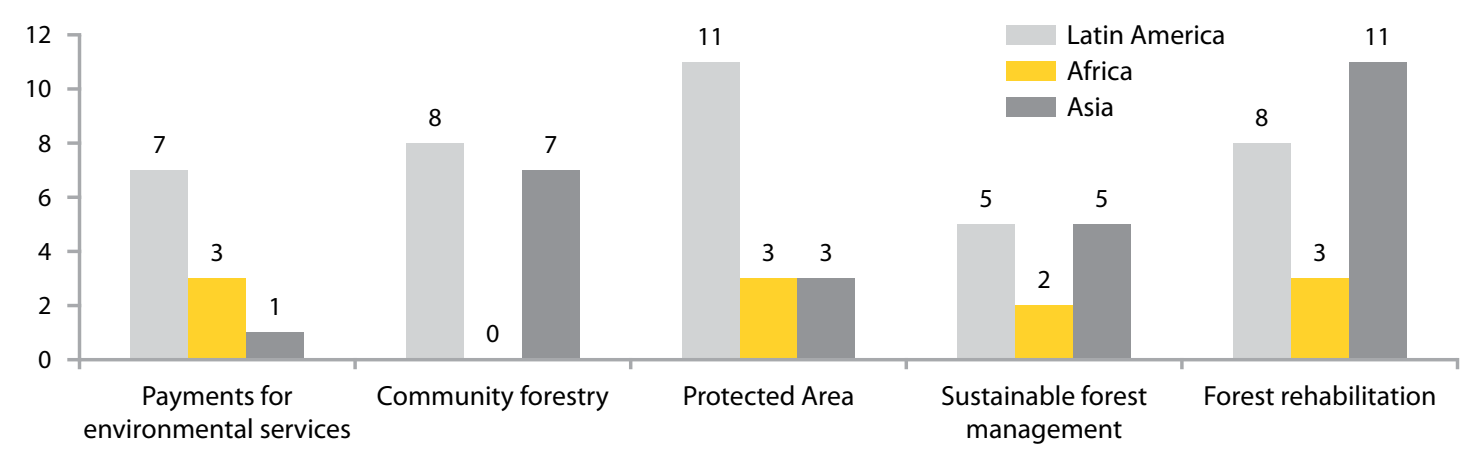

Figure 10. Stated objectives of REDD+ demonstration activities 
The graph shows that PES schemes play a less significant role in the surveyed REDD+ demonstration activities than expected. This finding is consistent with a study analysing REDD+ projects in Indonesia and finding that although these projects fit the definition at the scale that the carbon services are transacted, PES characteristics are not a main component of the on the ground implementation (Myers Madeira 2009). One reason therefore could be the governance or institutional constraints prevalent in many tropical forest areas, which make PES an option hardly feasible especially if formal tenure rights (including to carbon) are required. ${ }^{7}$ Yet, despite the value of governance investments as a direct means of reducing forest emissions (as alternatives to PES), carbon finance for REDD+ will require a performance-based approach, which will strengthen PES as an important instrument for REDD+. Therefore, national policy makers, donors and other investors in REDD+ demonstration activities need to invest in, and experiment further with, the potential for PES-type performance payments to reduce forest emissions in different socio-economic, institutional, and cultural contexts. 


\section{Preliminary conclusion}

The survey provides some preliminary insights from emerging REDD+ activities. While readiness activities are more or less evenly distributed across country and forest contexts, demonstration activities appear to be driven by carbon objectives - sometimes putting other noncarbon benefits at risk. This becomes especially clear when we examine how REDD+ activities are distributed across forest types. Dry forests - where many rural poor live, especially in Africa, and where there are high levels of biodiversity - are currently neglected as targets for REDD+ demonstration activities. Spatially explicit, high-resolution, environmental and socio-economic analysis offer new scope for targeting REDD+ investments to enhance carbon objectives while securing REDD+ co-benefits. Donors and other investors in REDD+ or REDD+ cobenefits could consider assembling such data to enhance their investment choices, monitor outcomes and, thus, learn valuable lessons to inform the national and global REDD+ architecture.
The survey further shows that REDD+ policies require more than PES. The fact that low governance is a widespread characteristic of many tropical forest areas across the globe calls for measures beyond PES-type deals, notably governance investments (e.g. enhanced command-and-control), to achieve cost-effective reductions in forest emissions. Finding the right mix of PES-type deals and governance investments in different country contexts is an important challenge ahead.

Donors and other investors in REDD+ demonstration activities could pay particular attention to appropriate policy measures (PES versus governance investments) to achieve emission reductions in given contexts. These will provide important inputs for national REDD+ policy makers as they consider suitable policy mixes for REDD+, and, ultimately, the global REDD+ architecture for financing REDD+. 
Anderson, P. and Kuswardono, T. 2008 Report to the Rainforest Foundation Norway on reducing emissions from deforestation and degradation in Indonesia. Rainforest Foundation, Oslo, Norway.

Angelsen, A. and Wertz-Kanounnikoff, S. 2008 What are the key design issues for REDD+ and the criteria for assessing options? In: A. Angelsen (ed.) Moving ahead with REDD+: Issues, options and implications, 11-22. CIFOR, Bogor, Indonesia.

Bond, I., Grieg-Gran, M., Wertz-Kanounnikoff, S., Hazlewood, P., Wunder, S. and Angelsen, A. 2009 Incentives to sustain forest ecosystem services: A review and lessons for REDD+. Natural Resource Issues No. 16. International Institute for Environment and Development, London, UK with CIFOR, Bogor, Indonesia, and World Resources Institute, Washington DC, USA.

Brown, D., Seymour, F. and Peskett, L. 2008 How do we achieve REDD+ co-benefits and avoid doing harm? In: A. Angelsen (ed.) Moving ahead with REDD+: Issues, options and implications, 107-118. CIFOR, Bogor, Indonesia.

Chomitz, K.M., Buys, P., Luca, G.D., Thomas, T.S. and Wertz-Kanounnikoff, S. 2007 At loggerheads?: Agricultural expansion, poverty reduction, and environment in the tropical forests. The World Bank, Washington, DC, USA.

da Fonseca, G.A.B., Rodriguez, C.M., Midgley, G., Busch, J., Hannah, L. and Mittermeier, R.A. 2007 No forest left behind. PLoS Biology 5(8): 1645-1646.

Dutschke, M., Wertz-Kanounnikoff, S., Peskett, L., Luttrell, C., Streck, C. and Brown, J. 2008 Mapping potential sources of REDD+ financing to different needs and national circumstances. CIFOR, Bogor, Indonesia, IPAM, Brasilia, Brazil; and ODI, London, UK.

Ebeling, J. and Yasue, M. 2008 Generating carbon finance through avoided deforestation and its potential to create climatic, conservation and human development benefits. Philosophical Transactions of The Royal Society B 363: 1917-1924.

Eliasch, J. 2008 Climate change: Financing global forests. The Stationery Office Limited, London. http://www. occ.gov.uk/activities/eliasch/Full_report_eliasch_ review(1) pdf.

Esty, D.C., Levy, M., Srebotnjak, T. and Sherbinin, A.D. 2005 Environmental Sustainability Index: Benchmarking national environmental stewardship. January 2005 Edition. Yale Center for Environmental Law and Policy, New Haven, CT, USA.
Food and Agriculture Organization of the United Nations (FAO) 2005 FRA 2005 global tables. In: The global forest resources assessment 2005. FAO, Rome, Italy.

Food and Agriculture Organization of the United Nations (FAO) 2007 State of the world's forests 2007. FAO, Rome, Italy.

Glenday, J. 2008 Carbon storage and emissions offset potential in an African dry forest, the Arabuko-Sokoke Forest, Kenya. Environmental Monitoring Assessment 142: 85-95.

Greenpeace 2009 Summary of the 'REDD+ from the Conservation Perspective' report, Commissioned by Greenpeace from the University of Freiburg Institute of Forest Policy, June 2009. www.greenpeace.org/raw/ content/usa/press-center/reports4/greenpeace-summaryof-the-red.pdf.

Grieg-Gran, M. 2008 The cost of avoiding deforestation: Update of the report prepared for the Stern Review of the Economics of Climate Change. International Institute for Environment and Development, London, UK.

Hansen, M.C. et al. 2008 Humid tropical forest clearing from 2000-2005 quantified by using multi-temporal and multi-resolution remotely sensed data. PNAS 105(27): 9439-9444.

Kaimowitz D. and Angelsen, A. 1999 Rethinking the causes of deforestation: Lessons from economic models. The World Bank Research Observer 14 (1): 73-98.

Kapos, V. et al. 2008 Carbon and biodiversity: A demonstration atlas. UNEP-WCMC, Cambridge, UK.

Kaufmann, D., Kraay, A. and Mastruzzi, M. 2008 Governance Matters VII: Governance Indicators for 1996-2007. The World Bank, Washington, DC, USA. http://info.worldbank.org/governance/wgi/pdf/ wgidataset.xls (accessed 03/05/2009).

Kishor N. and Damania, R. 2007 Crime and justice in the garden of Eden: improving governance and reducing corruption in the forestry sector. In: Campos, J.E. and Pradhan, S. (eds). The many faces of corruption: tracking vulnerability at the sector level. The World Bank, Washington, DC, USA.

Myers Madeira E., 2009 Assessment of reducing emissions from deforestation and forest degradation (REDD+) Activities in Indonesia and the Absence of PES-like Implementation Strategies. manuscript. 
Myers, N., Mittermeier, R.A., Mittermeier, C.G., da Fonseca, G.A.B. and Kent, J. 2000 Biodiversity hotspots for conservation priorities. Nature 403: 853-858.

Olson, D.M. et al. 2001 Terrestrial ecoregions of the world: A new map of life on earth. BioScience 51(11): 933-938.

Parker, C., Mitchell A., Trivedi M., and Mardas, M. 2009 The Little REDD+ + book. Global Canopy Programme, Oxford, UK.

Saatchi, S., Houghton, R.A., dos Santos, R.C., Avala, F., Soares, J. and Yu, Y. 2007 Distribution of above ground biomass in the Amazon Basin. Global Change Biology 13: 816-837.

Sunderlin, W.D., Hatcher, J. and Liddle, M. 2008 From exclusion to ownership?: Challenges and opportunities in advancing forest tenure reform. Rights and Resources Initiative, Washington, DC, USA.

Sunderlin, W.D., Dewi, S., Puntodewo, A., Mueller, D., Angelsen, A. and Epprecht, M. 2008 Why forests are important for global poverty alleviation: A spatial explanation. Ecology and Society 13(2) art. 24.
United Nations Development Programme (UNDP). 2007 Human development report 2007/2008. UNDP, New York, NY, USA.

Woods Hole Research Center (WHRC). 2009 An overview of readiness for REDD+: A complilation of readiness activities prepared on behalf of the forum on readiness for REDD+. Johns, T. and Johnson, E. (eds) Version 1.2 (March 2009). WHRC, Falmouth, MA, USA.

World Bank. 2008 Mapping of existing and emerging sources of forest financing. In: First design meeting on the forest investment program October 16-17, 2008. The World Bank, Washington, DC, USA.

Wunder, S. 2008. Necessary conditions for ccosystem service payments. $I n$ : Economics and conservation in the tropics: A strategic dialogue 31 Jan - 1 Feb 2008. Moore Foundation, Conservation Strategy Fund, and Resources for the Future, San Francisco, CA, USA.

Wunder S. 2005. Payments for environmental services: some nuts and bolts. Occasional Paper 42. CIFOR, Bogor, Indonesia. 
Annex 1. Overview of all REDD+ activities

\begin{tabular}{|c|c|c|c|c|c|c|c|c|}
\hline Country & $\begin{array}{l}\text { REDD+ } \\
\text { demon- } \\
\text { stration } \\
\text { activity }\end{array}$ & $\begin{array}{c}\text { REDD+ } \\
\text { readiness } \\
\text { activity }\end{array}$ & $\begin{array}{l}\text { UN-REDD } \\
\text { country } \\
\text { [yes = 1; } \\
\text { no }=0 \text { ] }\end{array}$ & $\begin{array}{c}\text { FCPF } \\
\text { country } \\
\text { [yes }=1 ; \\
\text { no }=0 \text { ] }\end{array}$ & $\begin{array}{l}\text { REDD+ demonstration } \\
\text { activity - planned }\end{array}$ & $\begin{array}{c}\text { REDD+ } \\
\text { demonstration } \\
\text { activity - } \\
\text { ongoing }\end{array}$ & $\begin{array}{l}\text { REDD+ } \\
\text { readiness } \\
\text { activity - } \\
\text { planned }\end{array}$ & $\begin{array}{c}\text { REDD+ } \\
\text { readiness } \\
\text { activity - } \\
\text { ongoing }\end{array}$ \\
\hline \multicolumn{9}{|c|}{ Asia } \\
\hline Cambodia & 1 & 1 & - & 1 & 1 & - & 1 & - \\
\hline Indonesia & 24 & 4 & 1 & 1 & 22 & 2 & 4 & - \\
\hline Lao PDR & - & 1 & - & 1 & - & - & 1 & - \\
\hline Nepal & - & 1 & - & 1 & - & - & 1 & - \\
\hline PNG & - & 3 & 1 & 1 & - & - & 3 & - \\
\hline Thailand & - & 1 & - & 1 & - & - & 1 & - \\
\hline Vanuatu & - & 2 & - & 1 & - & - & 1 & 1 \\
\hline Vietnam & - & 2 & 1 & 1 & - & - & 2 & - \\
\hline TOTAL & 25 & 15 & 3 & 8 & 23 & 2 & 14 & 1 \\
\hline \multicolumn{9}{|c|}{ Africa } \\
\hline Cameroon & 1 & 4 & - & 1 & 1 & - & 3 & 1 \\
\hline $\begin{array}{l}\text { Central African } \\
\text { Republic }\end{array}$ & - & 3 & - & 1 & - & - & 2 & 1 \\
\hline DR Congo & - & 4 & 1 & 1 & - & - & 4 & - \\
\hline Equatorial Guinea & - & 1 & - & 1 & - & - & 1 & - \\
\hline Ethiopia & - & 1 & - & 1 & - & - & 1 & - \\
\hline Gabon & - & 4 & - & 1 & - & - & 4 & - \\
\hline Ghana & - & 1 & - & 1 & - & - & 1 & - \\
\hline Guinea & - & 1 & - & - & - & - & 1 & - \\
\hline Kenya & - & 1 & - & 1 & - & - & 1 & - \\
\hline Liberia & - & 1 & - & 1 & - & - & 1 & - \\
\hline Madagascar & 4 & 2 & - & 1 & 1 & 3 & 2 & 1 \\
\hline Mozambique & - & 1 & - & 1 & - & - & 1 & - \\
\hline $\begin{array}{l}\text { Republic of } \\
\text { Congo }\end{array}$ & - & 2 & - & 1 & - & - & 2 & - \\
\hline Tanzania & - & 2 & 1 & 1 & - & - & 1 & - \\
\hline Uganda & - & 1 & - & 1 & - & - & 1 & - \\
\hline Zambia & - & 1 & 1 & - & - & - & 1 & - \\
\hline TOTAL & 5 & 30 & 3 & 14 & 2 & 3 & 27 & 3 \\
\hline \multicolumn{9}{|c|}{ Latin America } \\
\hline Argentina & - & 1 & - & 1 & - & - & 1 & - \\
\hline Bolivia & 1 & 2 & 1 & 1 & - & 1 & 2 & - \\
\hline Brazil & 5 & - & - & - & 2 & 3 & - & - \\
\hline Belize & 1 & - & - & - & - & 1 & - & - \\
\hline Chile & - & 1 & - & 1 & - & - & 1 & - \\
\hline Colombia & - & 2 & - & 1 & - & - & 1 & 1 \\
\hline Costa Rica & - & 1 & - & 1 & - & 1 & 1 & - \\
\hline Ecuador & 2 & - & - & - & 1 & 1 & - & - \\
\hline El Salvador & 2 & 1 & - & 1 & - & 1 & 1 & - \\
\hline Guatemala & 1 & 1 & - & 1 & - & 1 & 1 & - \\
\hline Guyana & - & 1 & - & 1 & - & - & 1 & - \\
\hline Honduras & - & 1 & - & 1 & - & - & 1 & - \\
\hline Mexico & - & 1 & - & 1 & - & - & 1 & - \\
\hline Nicaragua & - & 1 & - & 1 & - & - & 1 & - \\
\hline Paraguay & - & 2 & 1 & 1 & - & - & 1 & - \\
\hline Panama & 1 & 2 & 1 & 1 & 1 & - & 3 & - \\
\hline Peru & 1 & 2 & - & 1 & 1 & - & 2 & - \\
\hline Suriname & - & 1 & - & 1 & - & - & 1 & - \\
\hline TOTAL & 14 & 20 & 3 & 15 & 5 & 9 & 19 & 1 \\
\hline Overall Total & 44 & 65 & 9 & 37 & 30 & 14 & 60 & 5 \\
\hline
\end{tabular}

* Ongoing activities for all REDD+ types in Africa include REDD+ funds established to finance REDD+ activities. 
Annex 2. Overview of REDD+ demonstration activities ${ }^{8}$

\begin{tabular}{|c|c|c|c|c|c|c|c|c|c|c|c|c|}
\hline \multirow[t]{2}{*}{ Country } & \multirow[t]{2}{*}{ Readiness } & \multirow[t]{2}{*}{ PES } & \multirow[t]{2}{*}{$\begin{array}{c}\text { CB- } \\
\text { NRM }\end{array}$} & \multirow[t]{2}{*}{ PA } & \multirow[t]{2}{*}{ SFM } & \multirow[t]{2}{*}{ Rehab } & \multicolumn{3}{|c|}{$\begin{array}{c}\text { Size in ha } \\
\text { Small }<50000 \\
\text { Medium is } 50000-500000 \\
\text { Large }>500000\end{array}$} & \multirow[t]{2}{*}{$\begin{array}{c}\text { Sub- } \\
\text { national } \\
\text { initiative }\end{array}$} & \multirow[t]{2}{*}{$\begin{array}{l}\text { National } \\
\text { initiative }\end{array}$} & \multirow[t]{2}{*}{$\begin{array}{l}\text { Regional } \\
\text { initiative }\end{array}$} \\
\hline & & & & & & & Small & Med & Large & & & \\
\hline \multicolumn{13}{|c|}{ Asia } \\
\hline Cambodia & 1 & - & 1 & - & - & 1 & - & 1 & - & 1 & 1 & - \\
\hline Indonesia & 4 & - & 6 & 3 & 5 & 10 & 2 & 13 & 5 & 24 & 5 & - \\
\hline Lao PDR & 1 & - & - & - & - & - & - & - & - & - & 1 & - \\
\hline Nepal & 1 & - & - & - & - & - & - & - & - & - & 1 & - \\
\hline PNG & 3 & - & - & - & - & - & - & - & - & - & 3 & - \\
\hline Thailand & 1 & - & - & - & - & - & - & - & - & - & 1 & - \\
\hline Vanuatu & 2 & - & - & - & - & - & - & - & - & 1 & 1 & - \\
\hline Vietnam & 2 & 1 & - & - & - & - & - & - & - & 1 & 2 & - \\
\hline TOTAL & 15 & 1 & 7 & 3 & 5 & 11 & 2 & 14 & 5 & 27 & 15 & - \\
\hline \multicolumn{13}{|c|}{ Africa } \\
\hline Cameroon & 4 & - & - & - & - & - & - & - & 1 & - & 2 & 3 \\
\hline $\begin{array}{l}\text { Central African } \\
\text { Republic }\end{array}$ & 3 & 1 & - & - & - & - & - & - & 1 & - & 2 & 1 \\
\hline DR Congo & 4 & - & - & - & - & - & - & - & 1 & - & 3 & 2 \\
\hline Equatorial Guinea & 1 & - & - & - & - & - & - & - & - & - & 1 & - \\
\hline Ethiopia & 1 & - & - & - & - & - & - & - & - & - & 1 & - \\
\hline Gabon & 4 & - & - & - & - & - & - & - & 1 & - & 2 & 2 \\
\hline Ghana & 1 & - & - & - & - & - & - & - & - & - & 1 & - \\
\hline Guinea & 1 & - & - & - & - & - & - & - & - & - & - & 2 \\
\hline Kenya & 1 & - & - & - & - & - & - & - & - & - & 1 & - \\
\hline Liberia & 1 & - & - & - & - & - & - & - & - & - & 1 & - \\
\hline Madagascar & 2 & 1 & - & 3 & 1 & 2 & - & 4 & - & 4 & 1 & 1 \\
\hline Mozambique & 1 & 1 & - & - & 1 & 1 & - & - & - & 1 & 1 & - \\
\hline Republic of Congo & 2 & - & - & - & - & - & - & - & - & - & 1 & 1 \\
\hline Tanzania & 2 & - & - & - & - & - & - & - & - & - & 2 & - \\
\hline Uganda & 1 & - & - & - & - & - & - & - & - & - & 1 & - \\
\hline Zambia & 1 & - & - & - & - & - & - & - & - & - & 1 & - \\
\hline TOTAL & 30 & 3 & - & 3 & 2 & 3 & - & 4 & 4 & 5 & 21 & 12 \\
\hline \multicolumn{13}{|c|}{ Latin America } \\
\hline Argentina & 1 & - & - & - & - & - & - & - & - & - & 1 & - \\
\hline Bolivia & 2 & - & - & 1 & - & - & - & - & 1 & 1 & 2 & - \\
\hline Brazil & - & 3 & 3 & 2 & - & 3 & 1 & 2 & 2 & 7 & - & - \\
\hline Belize & - & - & - & 1 & 1 & - & 1 & - & - & 1 & - & - \\
\hline Chile & 1 & - & - & - & - & - & - & - & - & - & 1 & - \\
\hline Colombia & 2 & - & - & 1 & 1 & 1 & 1 & - & - & 2 & 1 & - \\
\hline Costa Rica & 1 & - & - & 1 & - & - & 2 & - & - & 1 & 1 & - \\
\hline Ecuador & - & 1 & 1 & 1 & - & 1 & - & 1 & 1 & 2 & - & - \\
\hline El Salvador & 1 & 2 & - & - & - & - & - & 1 & - & 2 & 1 & - \\
\hline Guatemala & 1 & - & 2 & - & - & 1 & - & 2 & - & 2 & 1 & - \\
\hline Guyana & 1 & - & - & - & - & - & - & - & - & - & 1 & - \\
\hline Honduras & 1 & - & - & 1 & 1 & 1 & 1 & - & - & 1 & 1 & - \\
\hline Mexico & 1 & - & 2 & - & 1 & 1 & 1 & - & 1 & 2 & 1 & - \\
\hline Nicaragua & 1 & - & - & - & - & - & - & - & - & - & 1 & - \\
\hline Paraguay & 2 & - & - & - & - & - & - & - & - & - & 2 & - \\
\hline Panama & 2 & - & - & 1 & - & - & 1 & - & - & 1 & 2 & - \\
\hline Peru & 2 & 1 & - & 2 & 1 & - & 1 & 2 & - & 3 & 1 & - \\
\hline Suriname & 1 & - & - & - & - & - & - & - & - & - & 1 & - \\
\hline TOTAL & 20 & 7 & 8 & 11 & 5 & 8 & 9 & 8 & 5 & 25 & 18 & - \\
\hline Overall Total & 65 & 11 & 15 & 17 & 12 & 22 & 11 & 26 & 14 & 57 & 54 & 12 \\
\hline
\end{tabular}

8 We abbreviate these activities as follows: payments for environmental services (PES), community-based natural resource management (CBNRM), protected area management (PA), sustainable forest management (SFM), forest restoration and rehabilitation (Rehab). 
Annex 3. REDD+ countries: Forest context

\begin{tabular}{|c|c|c|c|c|c|c|c|}
\hline \multirow[t]{2}{*}{ Country } & $\begin{array}{c}\text { Annual forest } \\
\text { cover change } \\
2000-2005 \\
{[\%]}\end{array}$ & $\begin{array}{c}\text { High/low } \\
\text { deforestation } \\
\text { country } \\
\text { [high }>0.5 \% \text {; } \\
\text { low }<0.5 \% \text { ] }\end{array}$ & $\begin{array}{c}\text { Forest area } \\
2005 \\
{[000 \mathrm{ha}]}\end{array}$ & $\begin{array}{c}\text { Land area } \\
\text { with forests } \\
{[\%]}\end{array}$ & $\begin{array}{c}\text { High/low } \\
\text { forest country } \\
\text { [high }>40 \% ; \\
\text { low }<40 \%]\end{array}$ & $\begin{array}{l}\text { Carbon in } \\
\text { above and } \\
\text { below ground } \\
\text { biomass } \\
\text { [tonnes/ha] }\end{array}$ & $\begin{array}{l}\text { Prominent forest } \\
\text { type }\end{array}$ \\
\hline & FAO 2005 & & FAO 2005 & FAO 2005 & & FAO 2007 & WWF 2001 \\
\hline \multicolumn{8}{|c|}{ Asia } \\
\hline Cambodia & -2.0 & high & 10447 & 59.2 & high & 151 & Humid-dry forests \\
\hline Indonesia & -2.0 & high & 67701 & 48.8 & high & 84 & Humid forests \\
\hline Lao PDR & -0.5 & high & 88495 & 69.9 & high & 115 & Humid forests \\
\hline Nepal & -1.4 & high & 3636 & 25.4 & low & 166 & $\mathrm{n} / \mathrm{a}^{\S}$ \\
\hline PNG & -0.5 & high & 29437 & 65.0 & high & $\mathrm{n} / \mathrm{a}$ & Humid forests \\
\hline Thailand & -0.4 & low & 14520 & 28.4 & low & 61 & Humid-dry forests \\
\hline Vanuatu & 0 & low & 440 & 36.1 & low & $\mathrm{n} / \mathrm{a}$ & Humid forests \\
\hline Vietnam & 2.0 & low & 12931 & 39.7 & low & 114 & Humid-dry forests \\
\hline \multicolumn{8}{|c|}{ Africa } \\
\hline Cameroon & -1.0 & high & 21245 & 45.6 & high & 113 & Humid-dry forests \\
\hline $\begin{array}{l}\text { Central African } \\
\text { Republic }\end{array}$ & -0.1 & low & 22755 & 36.5 & low & 154 & Dry forests \\
\hline DR Congo & -0.2 & low & 133610 & 58.9 & high & 216 & Humid-dry forests \\
\hline Equatorial Guinea & -0.9 & high & 1632 & 58.2 & high & 88 & Humid forests \\
\hline Ethiopia & -1.1 & high & 13000 & 11.9 & low & 24 & Dry forests \\
\hline Gabon & $\mathrm{n} / \mathrm{a}$ & $\mathrm{n} / \mathrm{a}$ & 21775 & 84.5 & high & 209 & Humid forests \\
\hline Ghana & -2.0 & high & 5517 & 24.2 & low & 113 & Humid-dry forests \\
\hline Guinea & -0.5 & high & 6724 & 27.4 & low & 119 & Dry forests \\
\hline Kenya & -0.3 & low & 3522 & 6.2 & low & 119 & Dry forests \\
\hline Liberia & -1.8 & high & 3154 & 32.7 & low & 180 & Humid forests \\
\hline Madagascar & -0.3 & low & 12838 & 22.1 & low & 305 & Humid-dry forests \\
\hline Mozambique & -0.3 & low & 19262 & 24.6 & low & 39 & Dry forests \\
\hline Republic of Congo & -0.1 & low & 22471 & 65.8 & high & 289 & Humid forests \\
\hline Tanzania & -1.1 & high & 35257 & 39.9 & low & 80 & Dry forests \\
\hline Uganda & -2.2 & high & 3627 & 18.4 & low & 48 & Dry forests \\
\hline Zambia & -1.0 & high & 42452 & 57.1 & high & 34 & Dry forests \\
\hline \multicolumn{8}{|c|}{ Latin America } \\
\hline Argentina & -0.4 & low & 33021 & 12.1 & low & 91 & Dry forest \\
\hline Bolivia & -0.5 & high & 58740 & 54.2 & high & 113 & Humid-dry forests \\
\hline Brazil & -0.6 & high & 477698 & 72.5 & high & 129 & Humid forests \\
\hline Belize & 0 & low & 1653 & 57.2 & high & 45 & Humid forests \\
\hline Chile & 0.4 & low & 16121 & 21.5 & low & 151 & $\mathrm{n} / \mathrm{a}$ \\
\hline Colombia & -0.1 & low & 60728 & 58.5 & high & 166 & Humid forests \\
\hline Costa Rica & 0.1 & low & 2391 & 46.8 & high & 101 & Humid forests \\
\hline Ecuador & -1.7 & high & 10853 & 39.2 & low & $\mathrm{n} / \mathrm{a}$ & Humid forests \\
\hline El Salvador & -1.7 & high & 298 & 14.4 & low & $\mathrm{n} / \mathrm{a}$ & Dry forests \\
\hline Guatemala & -1.3 & high & 3938 & 36.3 & low & 158 & Humid forests \\
\hline Guyana & 0 & low & 15104 & 76.7 & high & 143 & Humid forests \\
\hline Honduras & -3.1 & high & 4648 & 41.5 & high & $\mathrm{n} / \mathrm{a}$ & Dry forests \\
\hline Mexico & -0.4 & low & 64238 & 33.7 & low & $\mathrm{n} / \mathrm{a}$ & Humid-dry forests \\
\hline Nicaragua & -1.3 & high & 5189 & 42.7 & high & 173 & Humid forests \\
\hline Paraguay & -0.9 & high & 18475 & 46.5 & high & $\mathrm{n} / \mathrm{a}$ & Dry forests \\
\hline Panama & -0.1 & low & 4294 & 57.7 & high & 180 & Humid forests \\
\hline Peru & -0.1 & low & 68742 & 53.7 & high & $\mathrm{n} / \mathrm{a}$ & Humid forests \\
\hline Suriname & 0 & low & 14776 & 94.7 & high & 481 & Humid forests \\
\hline
\end{tabular}


Annex 4. REDD+ countries: Governance context

\begin{tabular}{|c|c|c|c|c|c|c|c|c|}
\hline Countries & $\begin{array}{l}\text { Community owned } \\
\text { or managed }\end{array}$ & $\begin{array}{c}\text { Public } \\
\text { forest (\%) }\end{array}$ & $\begin{array}{l}\text { Private } \\
\text { forest (\%) }\end{array}$ & Rule of law & $\begin{array}{l}\text { Control of } \\
\text { Corruption }\end{array}$ & $\begin{array}{l}\text { Gover- } \\
\text { nance } \\
\text { mean }\end{array}$ & $\begin{array}{l}\text { GDP per } \\
\text { capita }\end{array}$ & $\begin{array}{l}\text { National bio- } \\
\text { diversity index }\end{array}$ \\
\hline & Chomitz et al. 2006 & FAO 2005 & FAO 2005 & $\begin{array}{l}\text { World Bank } \\
2008\end{array}$ & $\begin{array}{l}\text { World Bank } \\
2008\end{array}$ & & UNDP 2007 & Esty et al. 2005 \\
\hline \multicolumn{9}{|c|}{ Asia } \\
\hline Cambodia & Low & 100 & 0 & -1.06 & -1.08 & -1.07 & 564 & -0.35 \\
\hline Indonesia & Low & 100 & 0 & -0.71 & -0.72 & -0.72 & 1651 & -0.14 \\
\hline Laos PDR & n.a. & 100 & 0 & -0.96 & -1 & -0.98 & 567 & -0.16 \\
\hline Nepal & n.a. & 99.93 & 0.05 & -0.64 & -0.66 & -0.65 & 346 & -0.05 \\
\hline PNG & High & n.a. & $<3$ & -0.85 & -1.05 & -0.95 & 900 & 0.15 \\
\hline Thailand & Low & 13 & 87 & -0.06 & -0.44 & -0.25 & 3397 & -0.12 \\
\hline Vanuatu & High & 0 & 0 & 0.63 & 0.21 & 0.42 & n.a. & n.a. \\
\hline Vietnam & Medium & 56 & 18 & -0.53 & -0.69 & -0.61 & 791 & -0.35 \\
\hline \multicolumn{9}{|c|}{ Africa } \\
\hline Cameroon & Medium & 100 & 0 & -1.09 & -0.93 & -1.01 & 1026 & 0.40 \\
\hline CAR & Low & n.a. & n.a. & -1.52 & -0.9 & -1.21 & 425 & 0.68 \\
\hline DR Congo & Low & 100 & 0 & -1.67 & -1.27 & -1.47 & 139 & 0.60 \\
\hline Equatorial guinea & n.a. & n.a. & n.a. & -1.16 & -1.37 & -1.27 & n.a. & n.a. \\
\hline Ethiopia & n.a. & 100 & 0 & -0.54 & -0.7 & -0.62 & 223 & 0.08 \\
\hline Gabon & Low & 100 & 0 & -0.6 & -0.85 & -0.73 & n.a. & 0.78 \\
\hline Ghana & Low & 100 & 0 & -0.08 & -0.17 & -0.13 & 604 & 0.18 \\
\hline Guinea & n.a. & n.a. & n.a. & -1.47 & -1.33 & -1.40 & 411 & 0.16 \\
\hline Kenya & n.a. & 94 & 5 & -0.98 & -0.94 & -0.96 & 674 & 0.45 \\
\hline Liberia & Low & n.a. & n.a. & -1.06 & -0.41 & -0.74 & 150 & -0.02 \\
\hline Madagascar & n.a. & 98 & 2 & -0.35 & -0.16 & -0.26 & 315 & -0.57 \\
\hline Mozambique & n.a. & 100 & 0 & -0.68 & -0.59 & -0.64 & 324 & 0.46 \\
\hline Republic of Congo & Low & 100 & 0 & -1.26 & -1.04 & -1.15 & 1450 & 0.84 \\
\hline Tanzania & n.a. & 94 & $<1$ & -0.45 & -0.45 & -0.45 & 408 & 0.23 \\
\hline Uganda & n.a. & 24 & 76 & -0.54 & -0.76 & -0.65 & 339 & 0.51 \\
\hline Zambia & n.a. & 100 & 0 & -0.64 & -0.6 & -0.62 & 792 & 0.77 \\
\hline \multicolumn{9}{|c|}{ Latin America } \\
\hline Argentina & n.a. & n.a. & n.a. & -0.52 & -0.45 & -0.49 & 5973 & 0.10 \\
\hline Belize & n.a. & n.a. & n.a. & 0.02 & -0.27 & -0.13 & n.a. & n.a. \\
\hline Bolivia & Medium & 85 & 10 & -0.96 & -0.49 & -0.73 & 1200 & 0.79 \\
\hline Brazil & Medium & n.a. & n.a. & -0.44 & -0.24 & -0.34 & 5901 & 0.09 \\
\hline Chile & n.a. & 25 & 73 & 1.17 & 1.35 & 1.26 & 8153 & -0.50 \\
\hline Colombia & Medium & n.a. & n.a. & -0.57 & -0.28 & -0.43 & 3259 & 0.32 \\
\hline Costa Rica & n.a. & n.a. & n.a. & 0.44 & 0.39 & 0.42 & 6200 & 0.38 \\
\hline Ecuador & Medium & 77 & 0 & -1.04 & -0.87 & -0.96 & 3169 & 0.21 \\
\hline El Salvador & n.a. & 72 & 25 & -0.68 & -0.13 & -0.41 & 2786 & 0.36 \\
\hline Guatemala & Medium & 42 & 53 & -1.11 & -0.75 & -0.93 & 2508 & 0.37 \\
\hline Guyana & Medium & 66 & 0 & -0.57 & -0.64 & -0.61 & n.a. & 0.88 \\
\hline Honduras & Medium & 75 & 25 & -0.86 & -0.69 & -0.78 & 1614 & -0.07 \\
\hline Mexico & High & 59 & 0 & -0.58 & -0.35 & -0.47 & 8362 & -0.05 \\
\hline Nicaragua & n.a. & n.a. & n.a. & -0.84 & -0.78 & -0.81 & 917 & 0.58 \\
\hline Panama & Medium & 10 & 90 & -0.2 & -0.34 & -0.27 & 6133 & 0.45 \\
\hline Paraguay & n.a. & 94 & 5 & -0.97 & -0.96 & -0.97 & 1700 & 0.57 \\
\hline Peru & Medium & 83 & 15 & -0.71 & -0.38 & -0.55 & 3436 & 0.55 \\
\hline Suriname & Low & n.a. & 0 & -0.24 & -0.26 & -0.25 & n.a. & n.a. \\
\hline
\end{tabular}



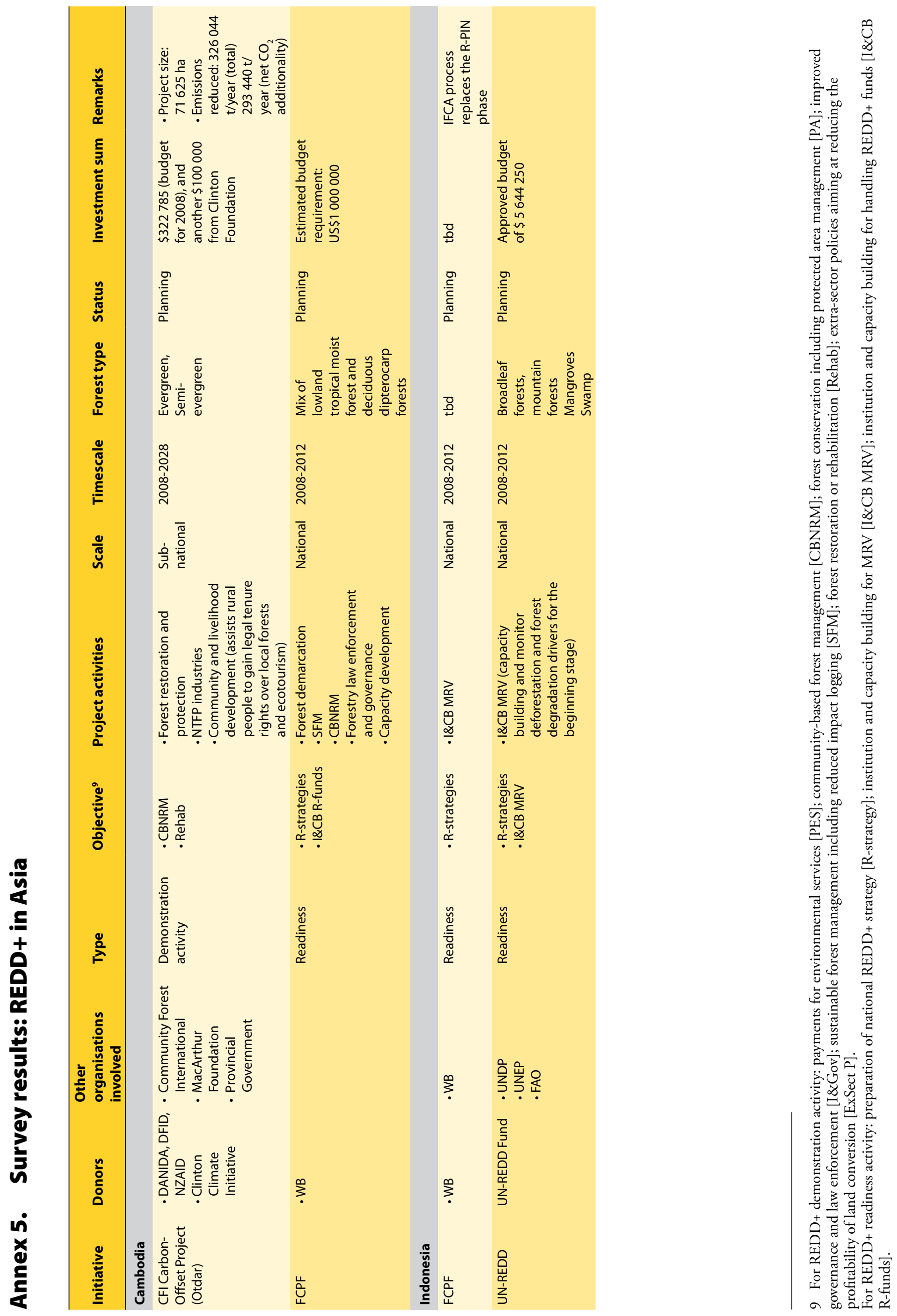


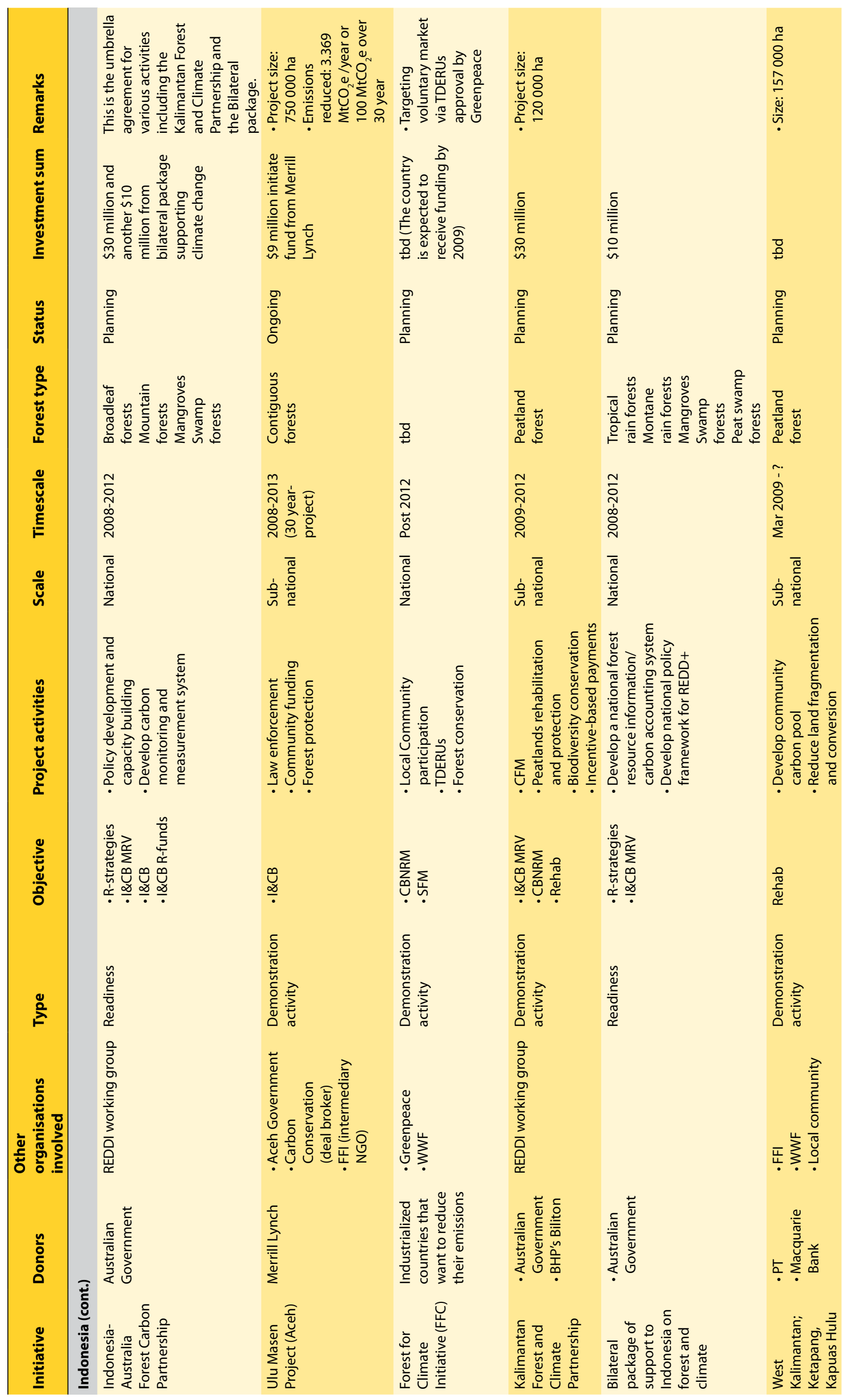




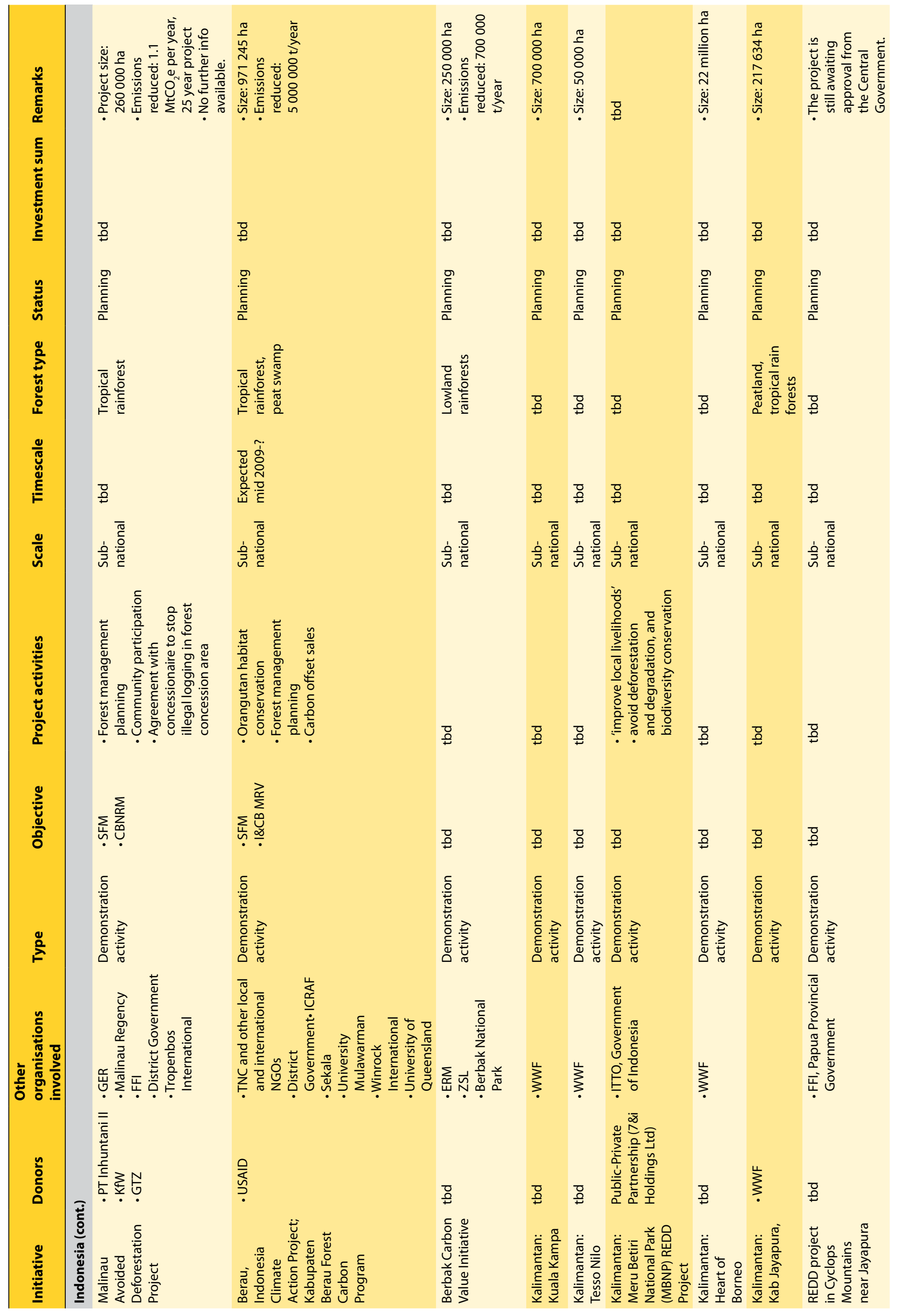




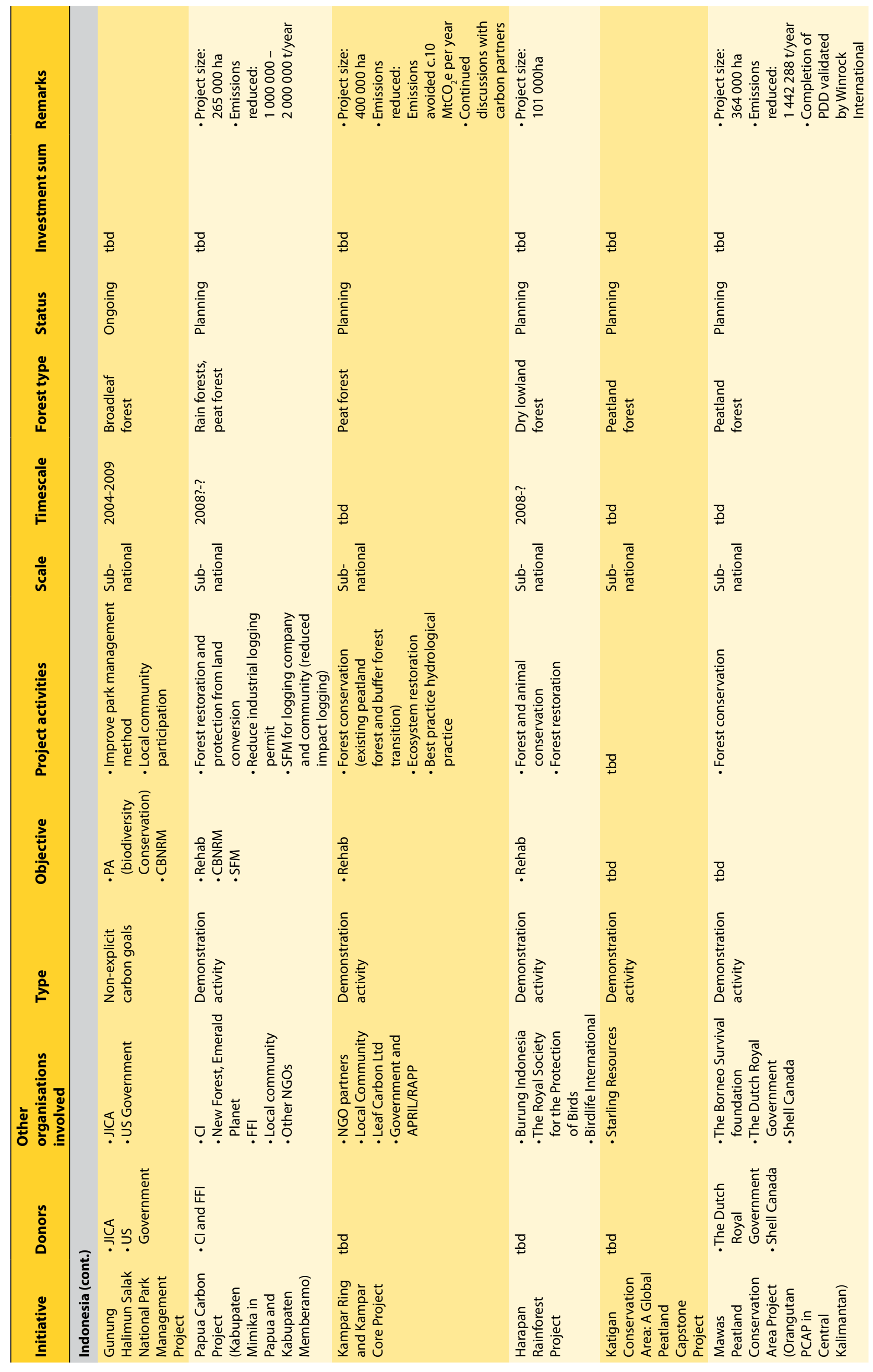




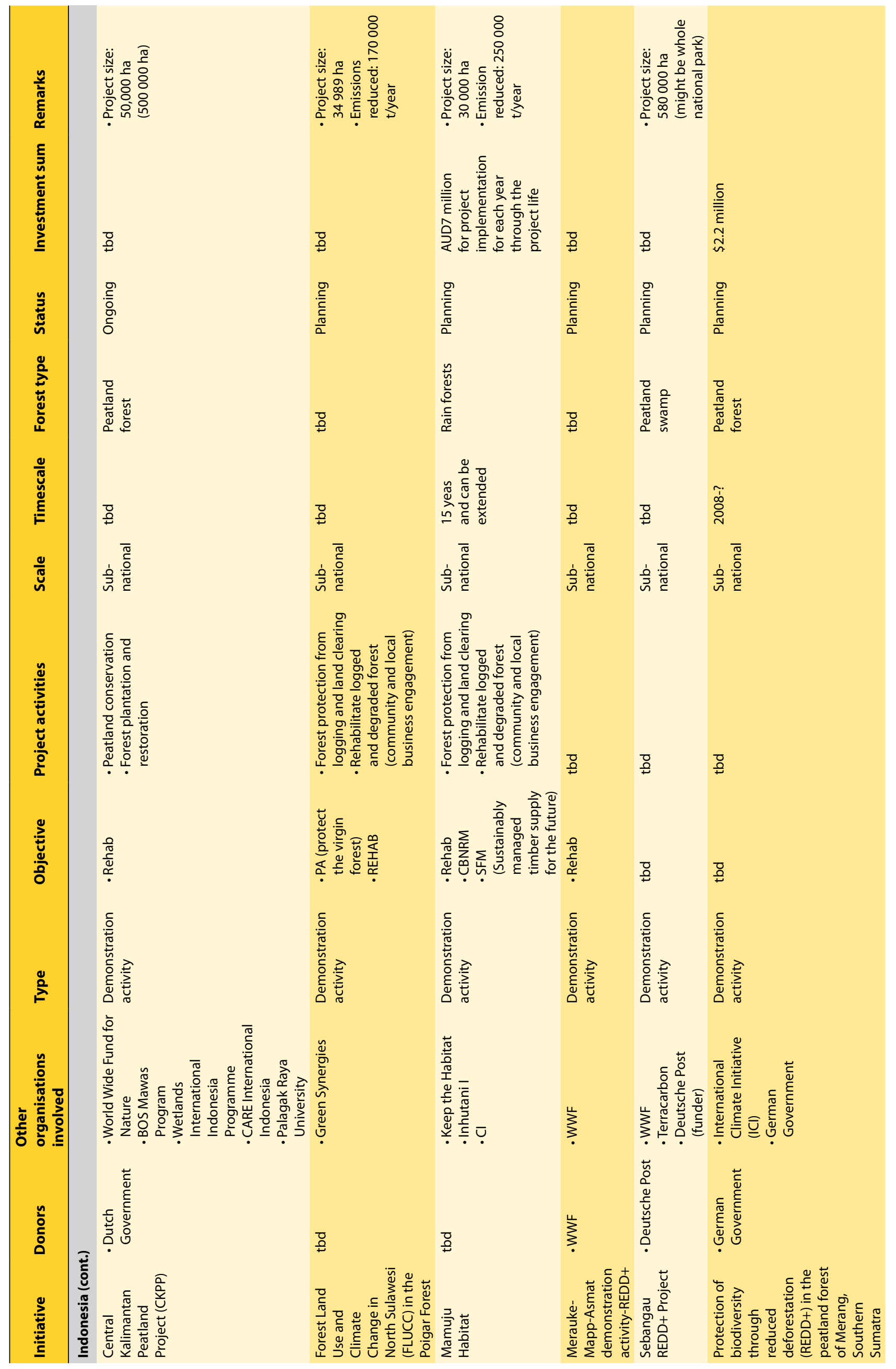




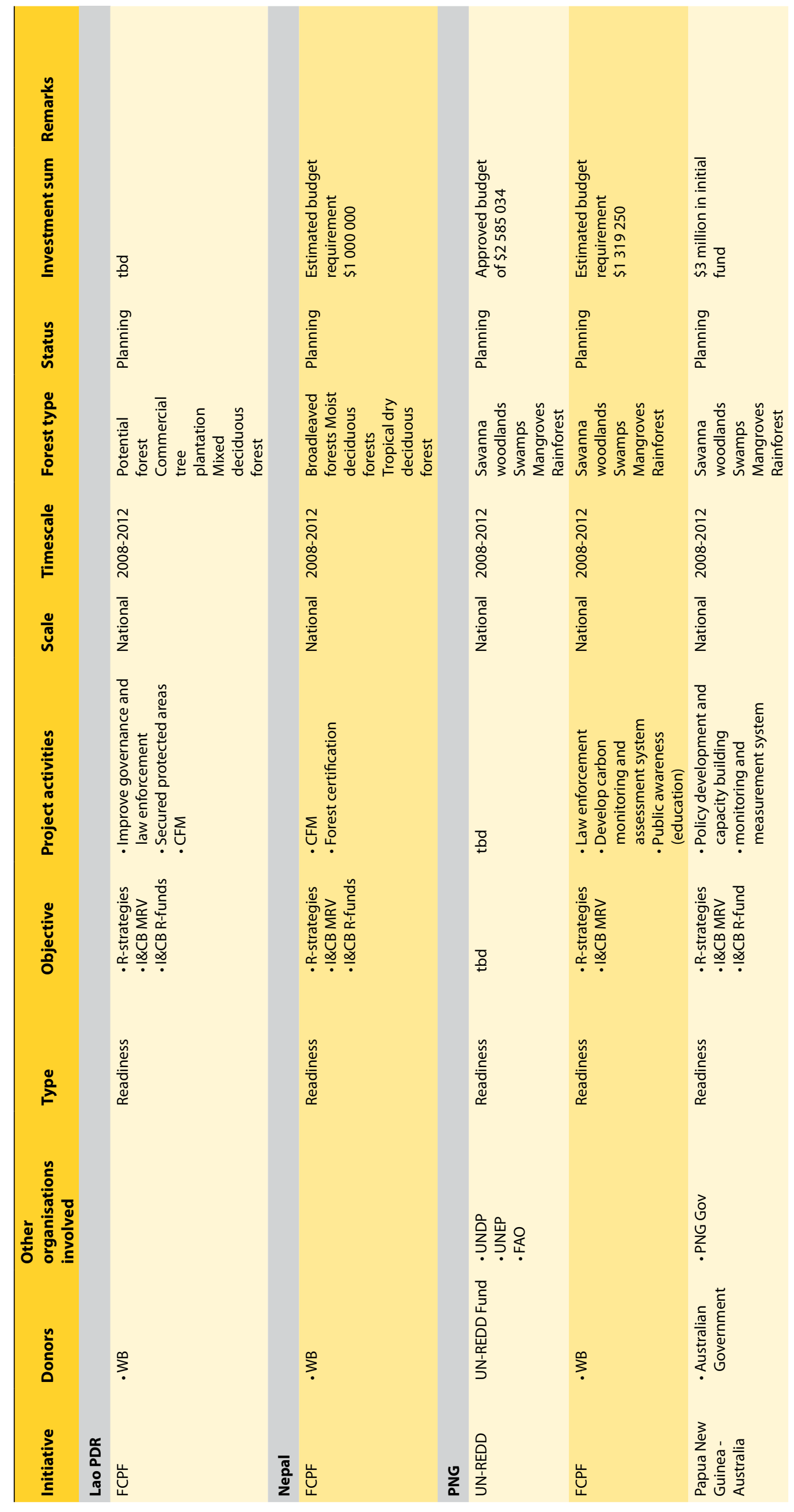




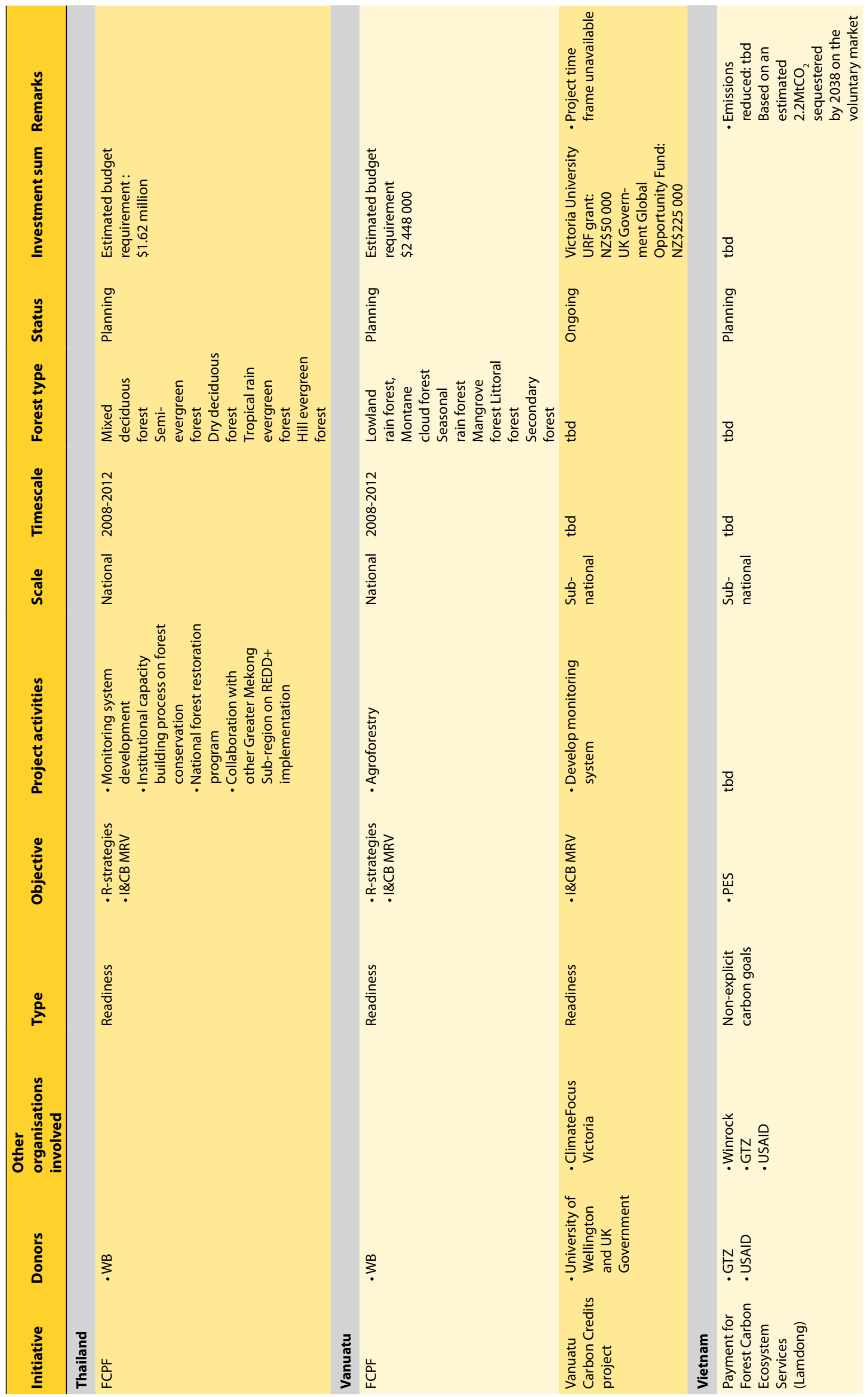




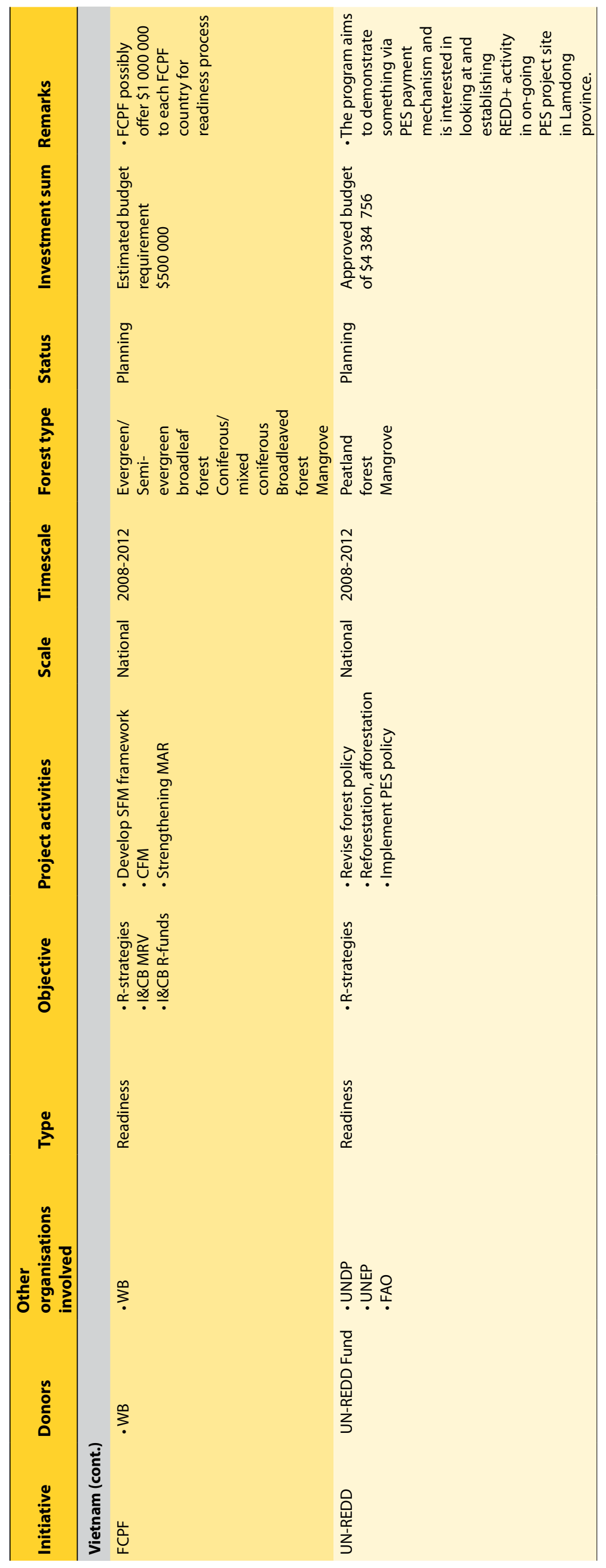




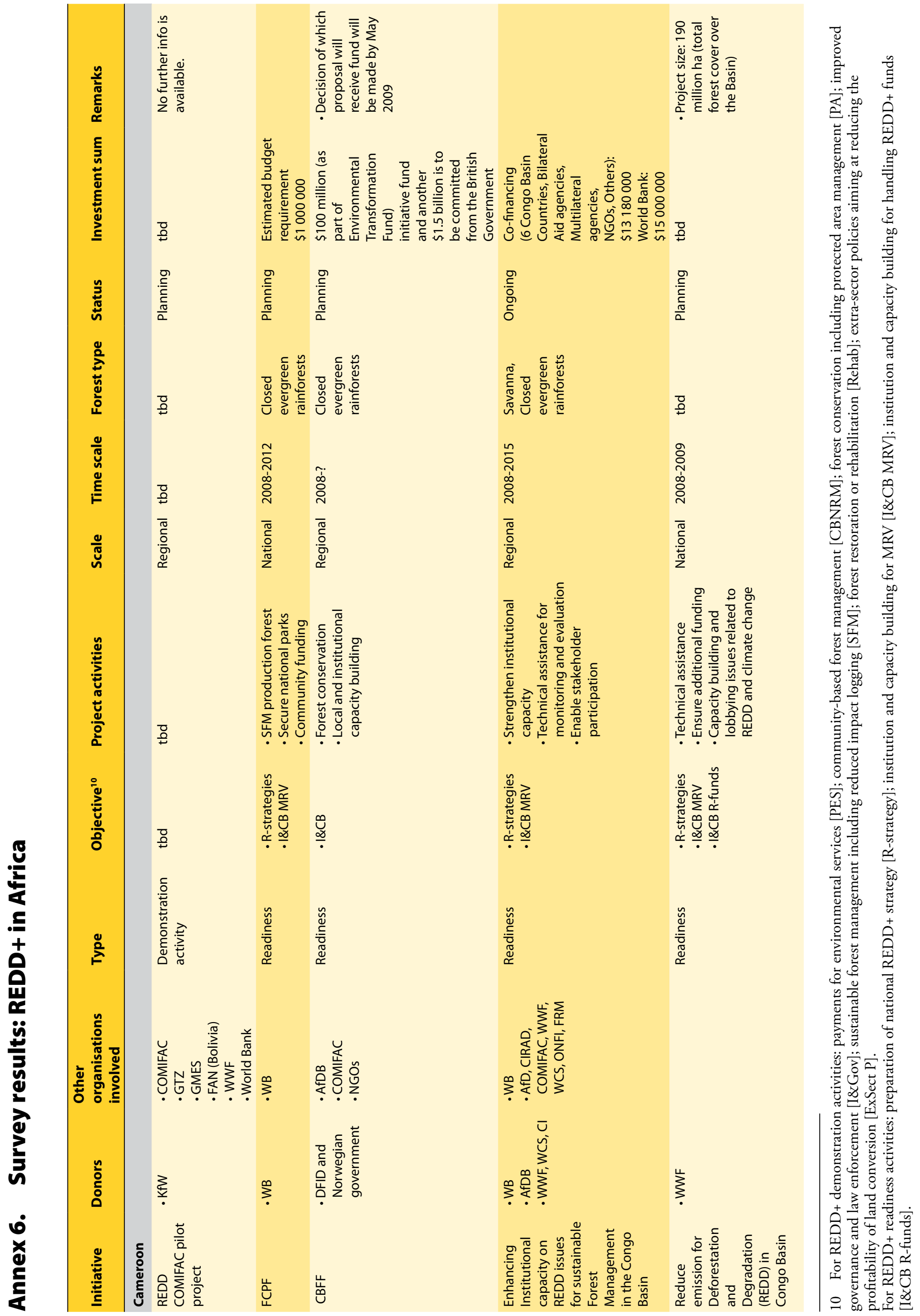




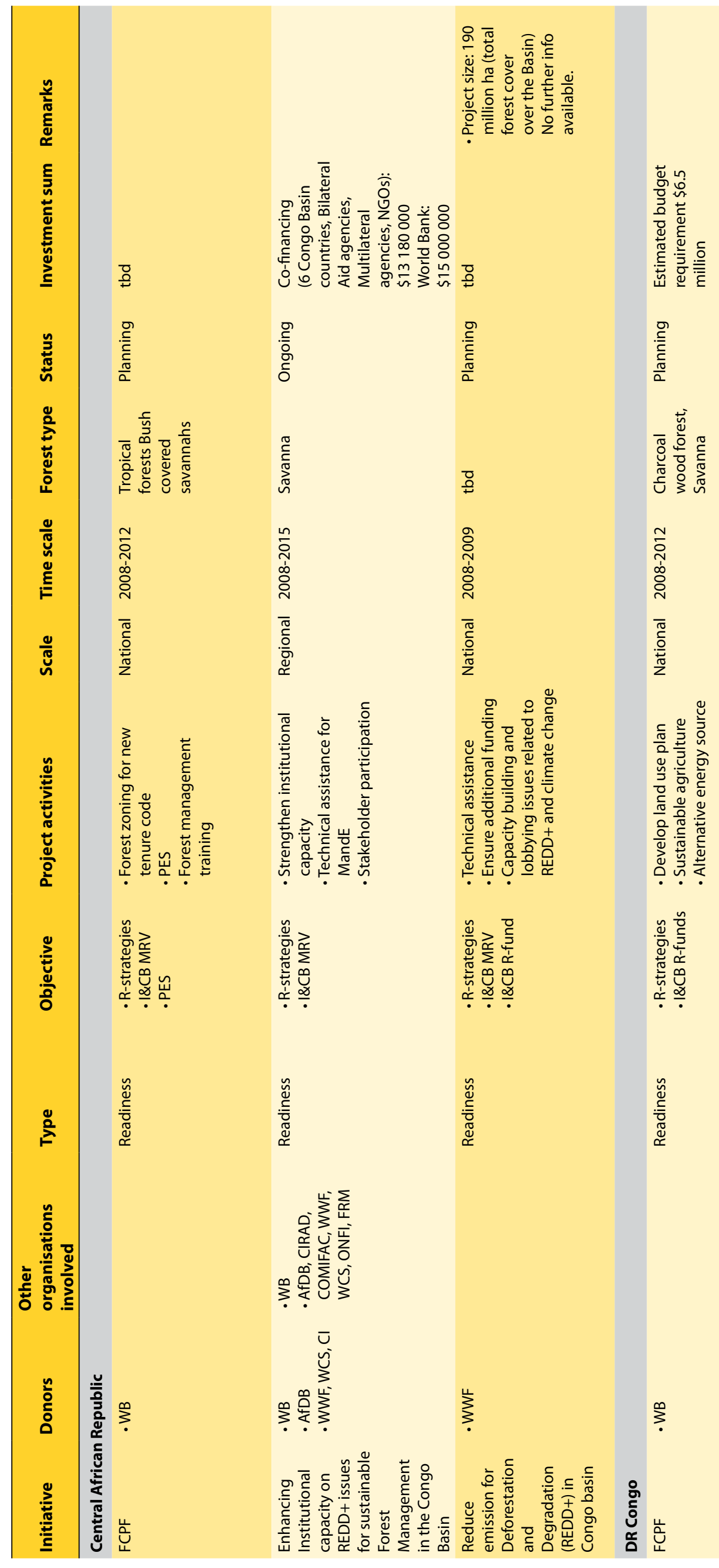




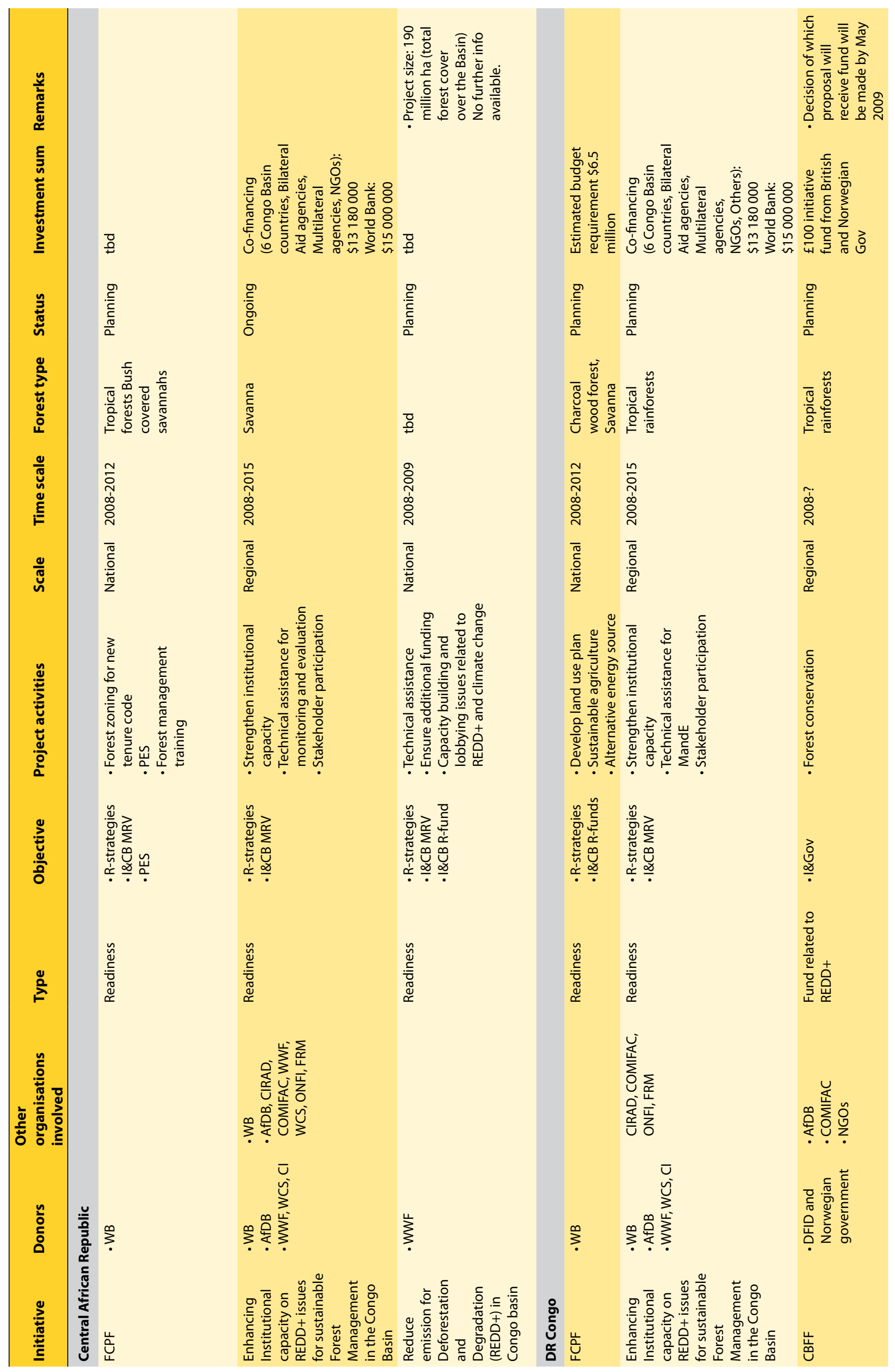




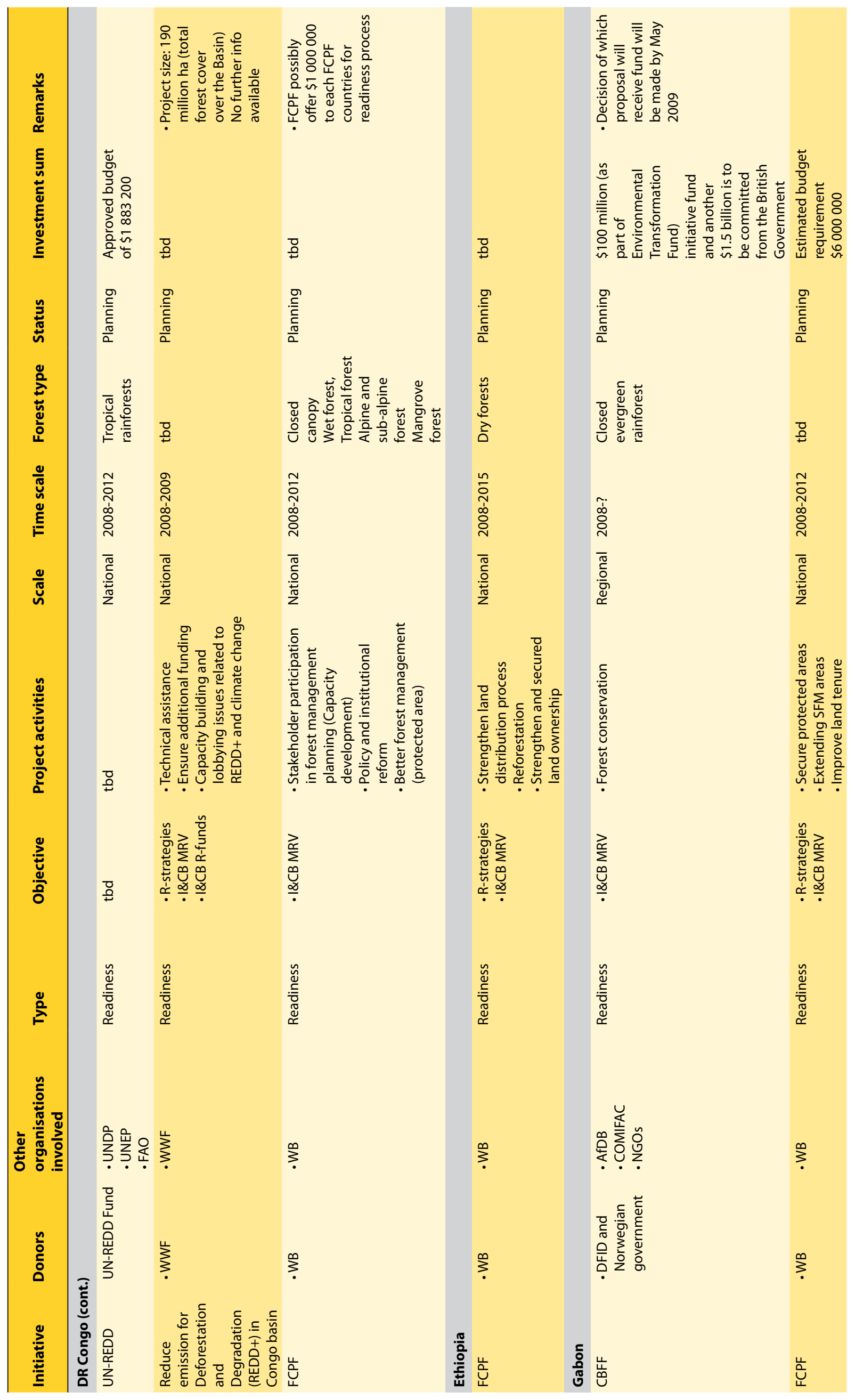




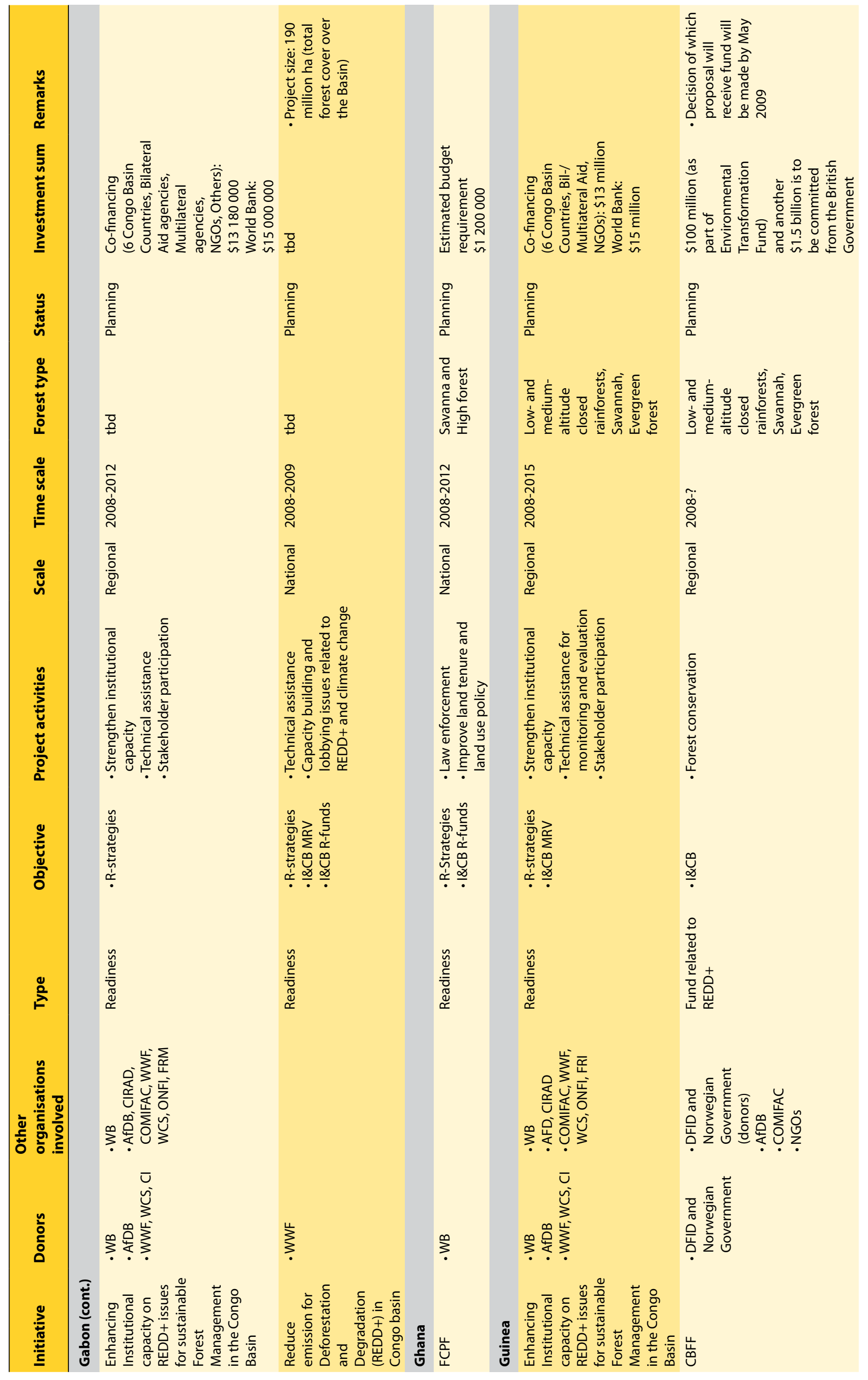




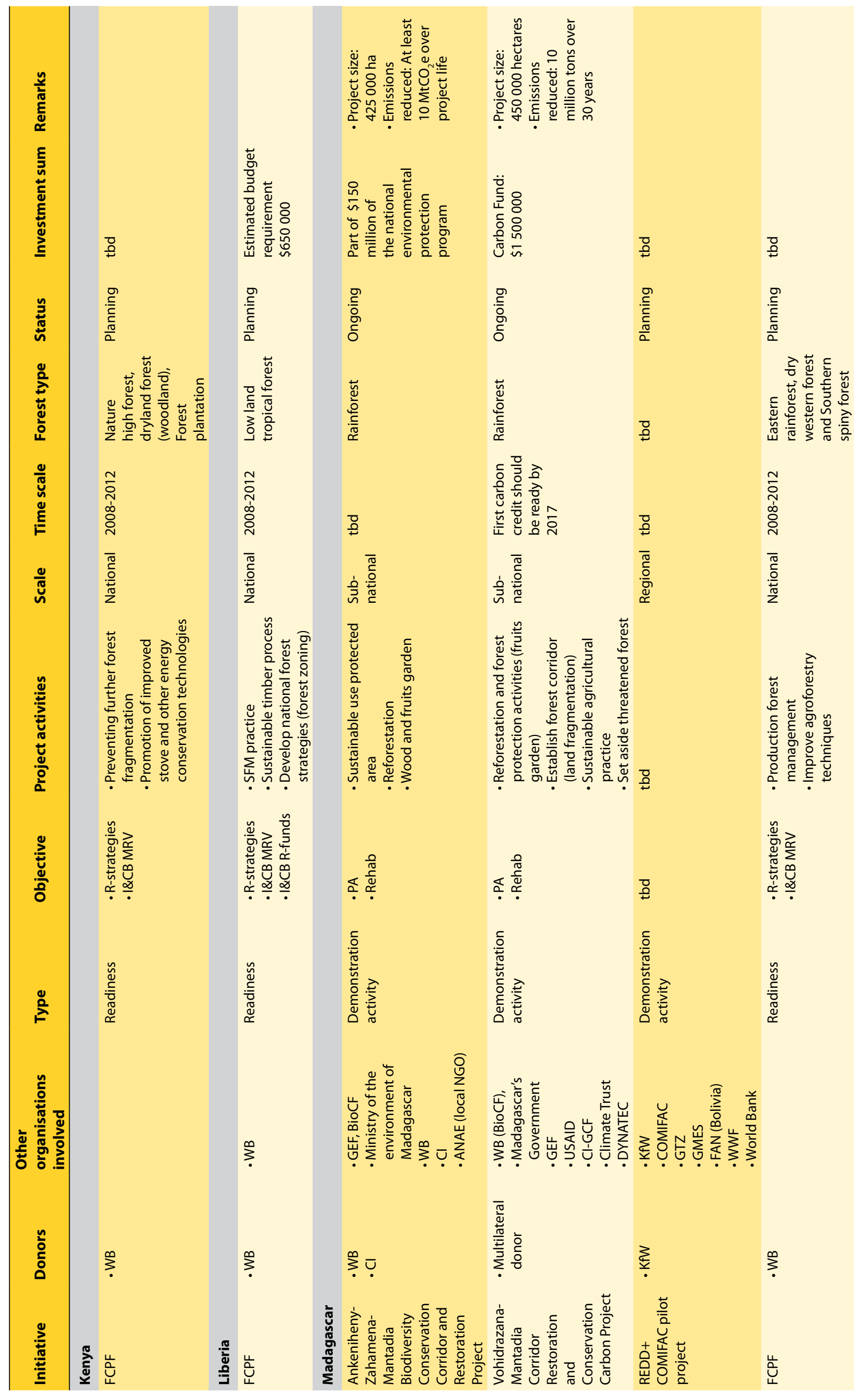




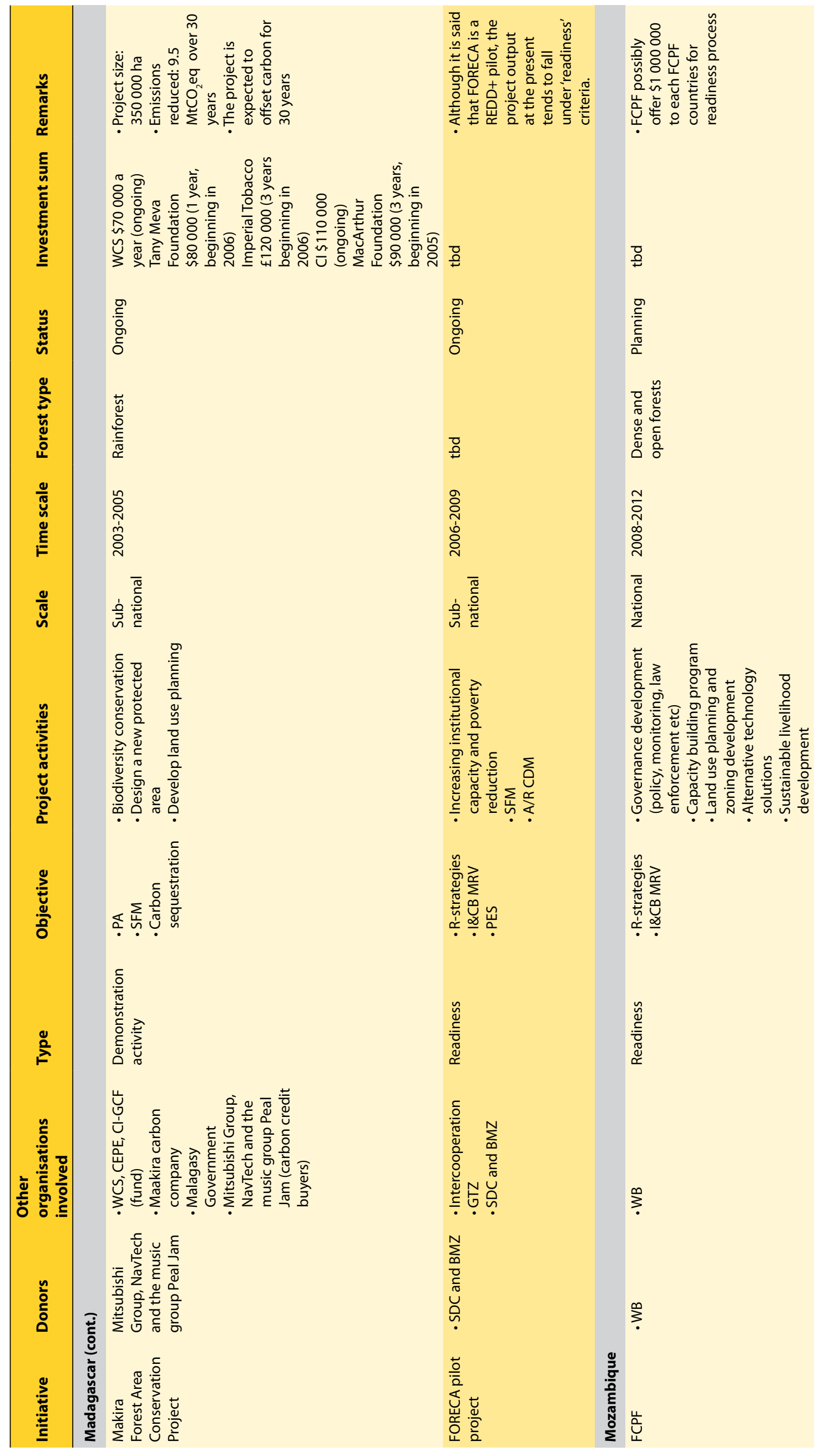




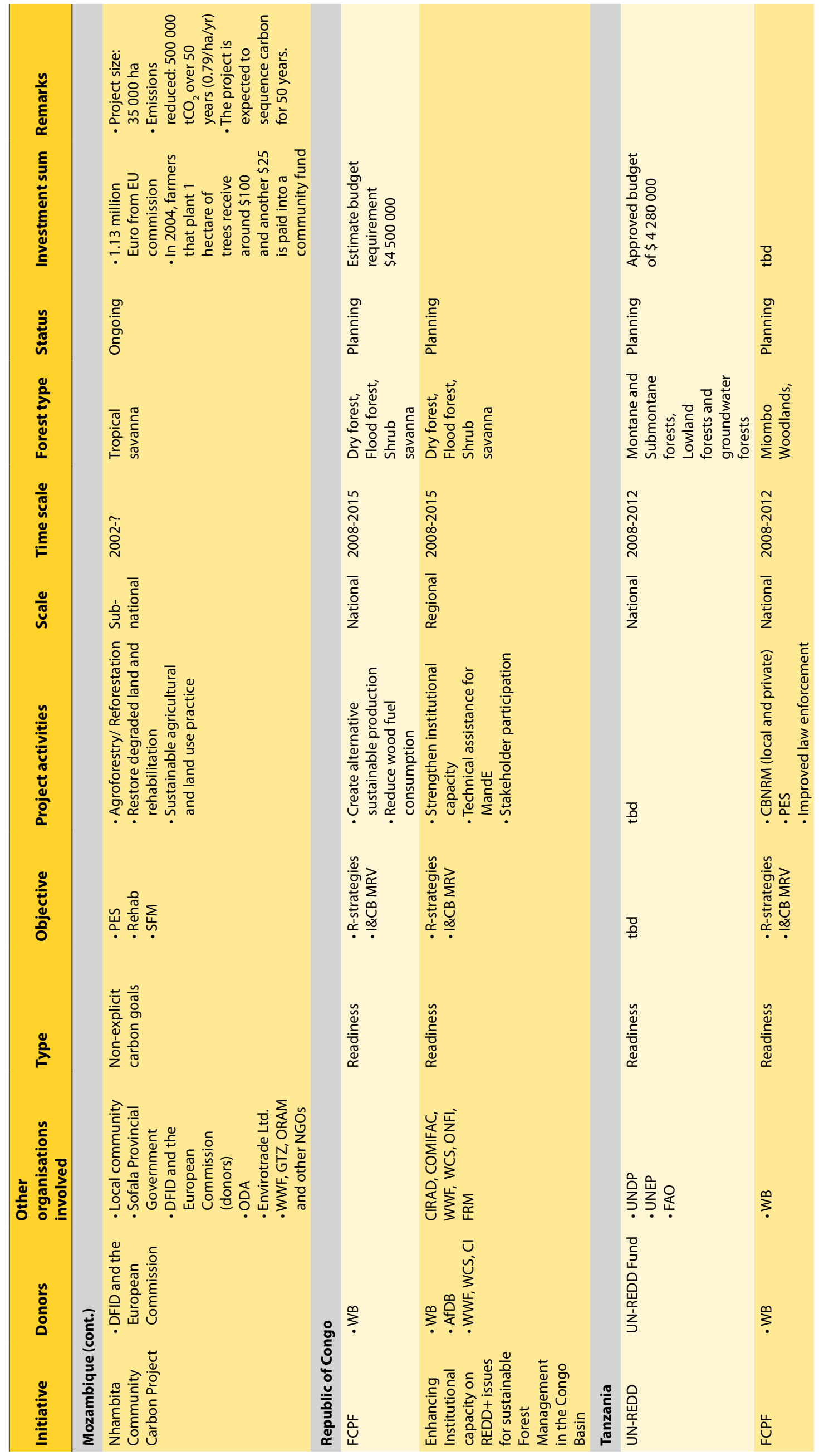




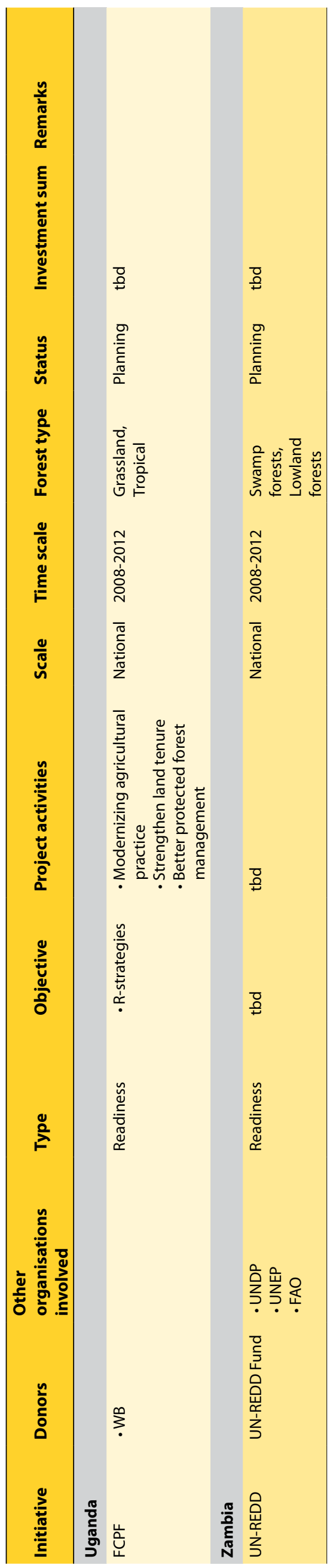




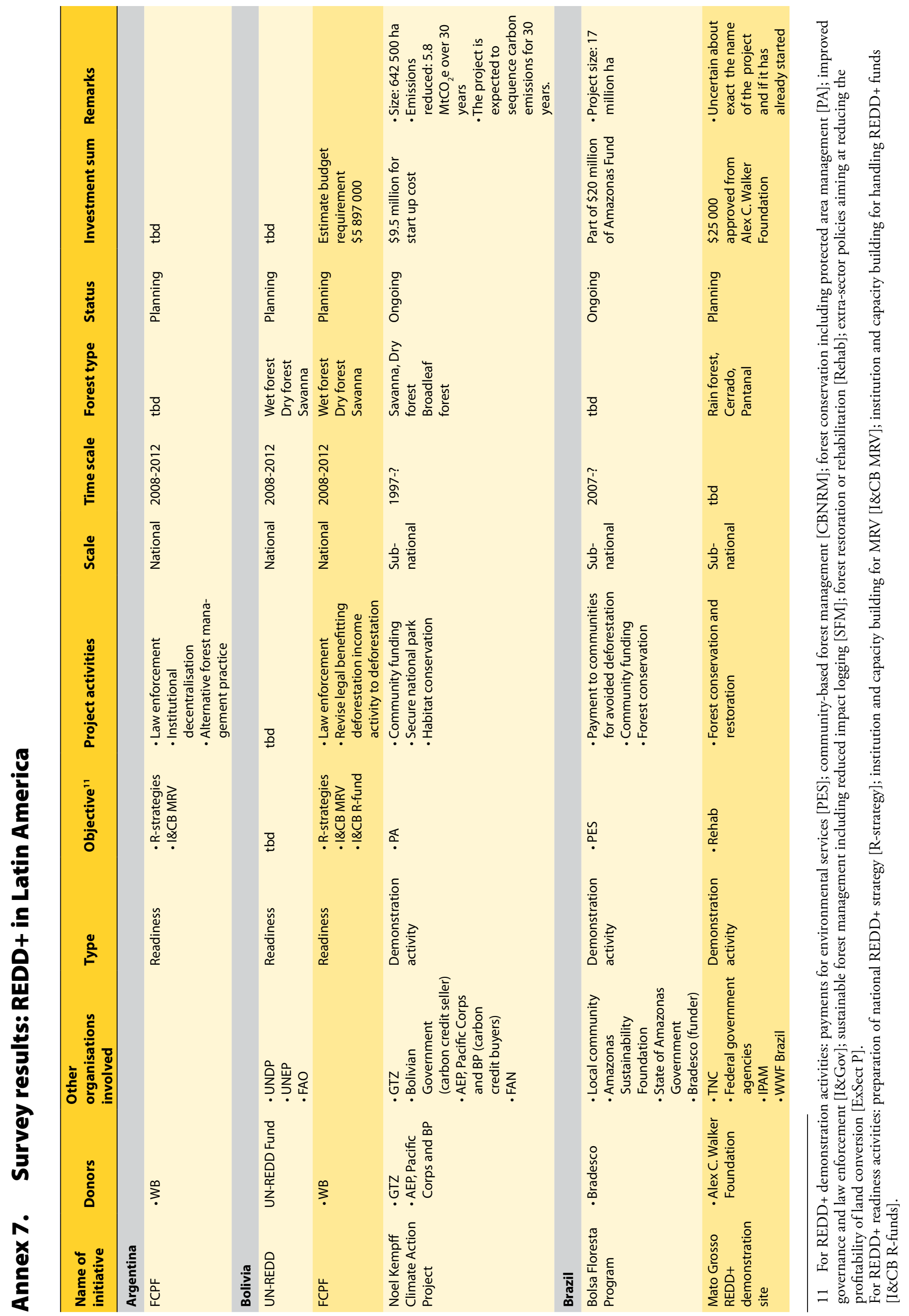




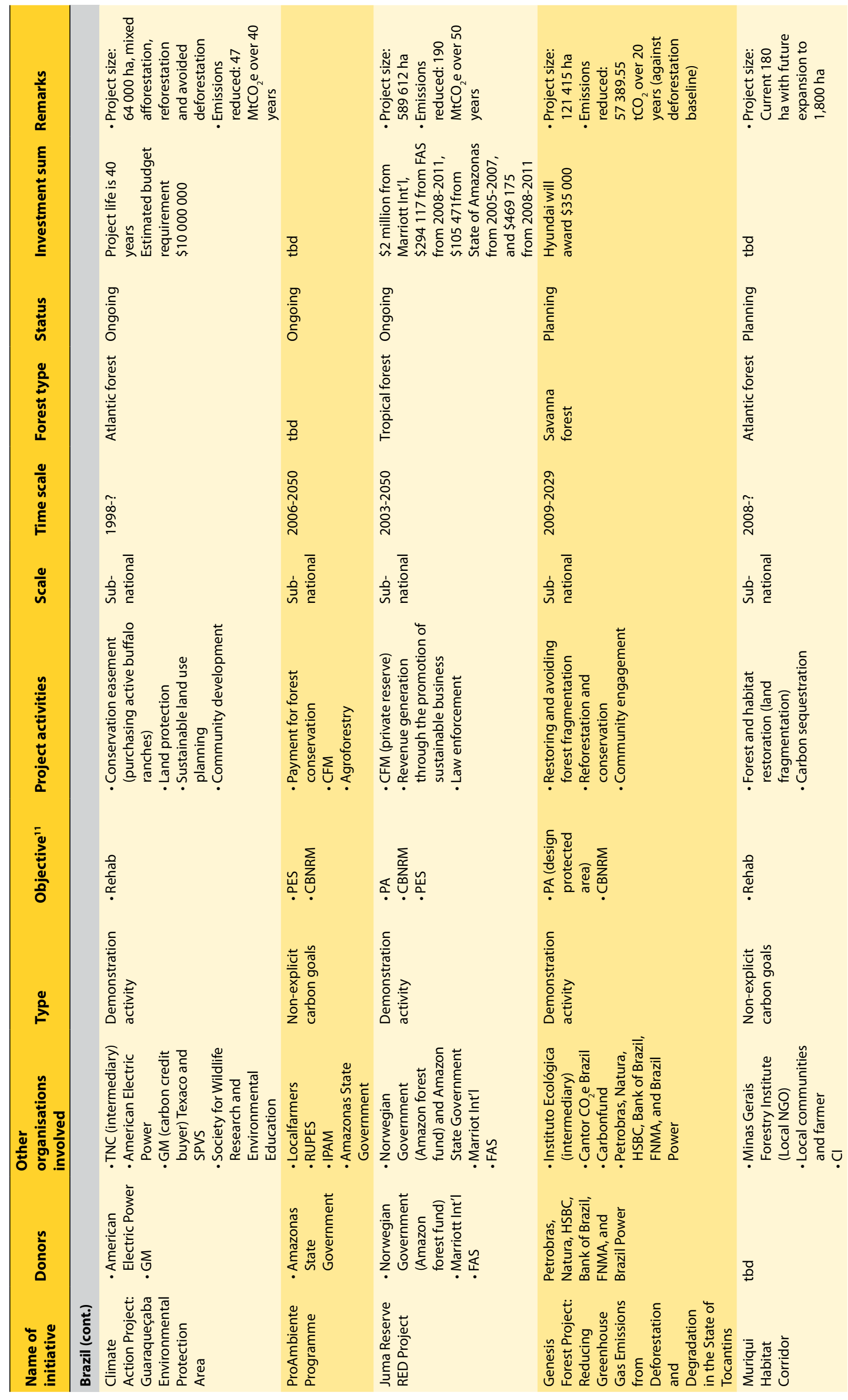




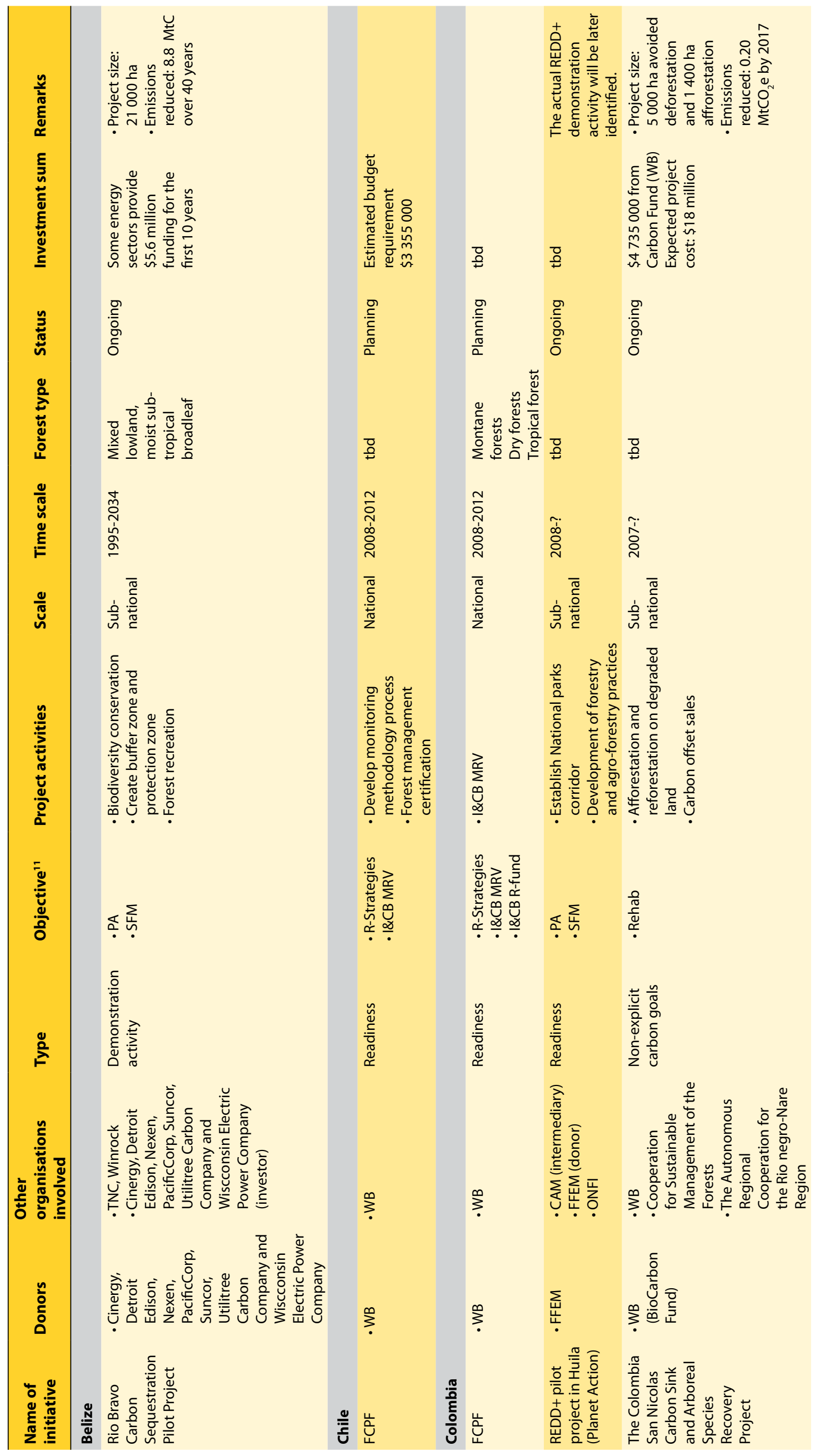




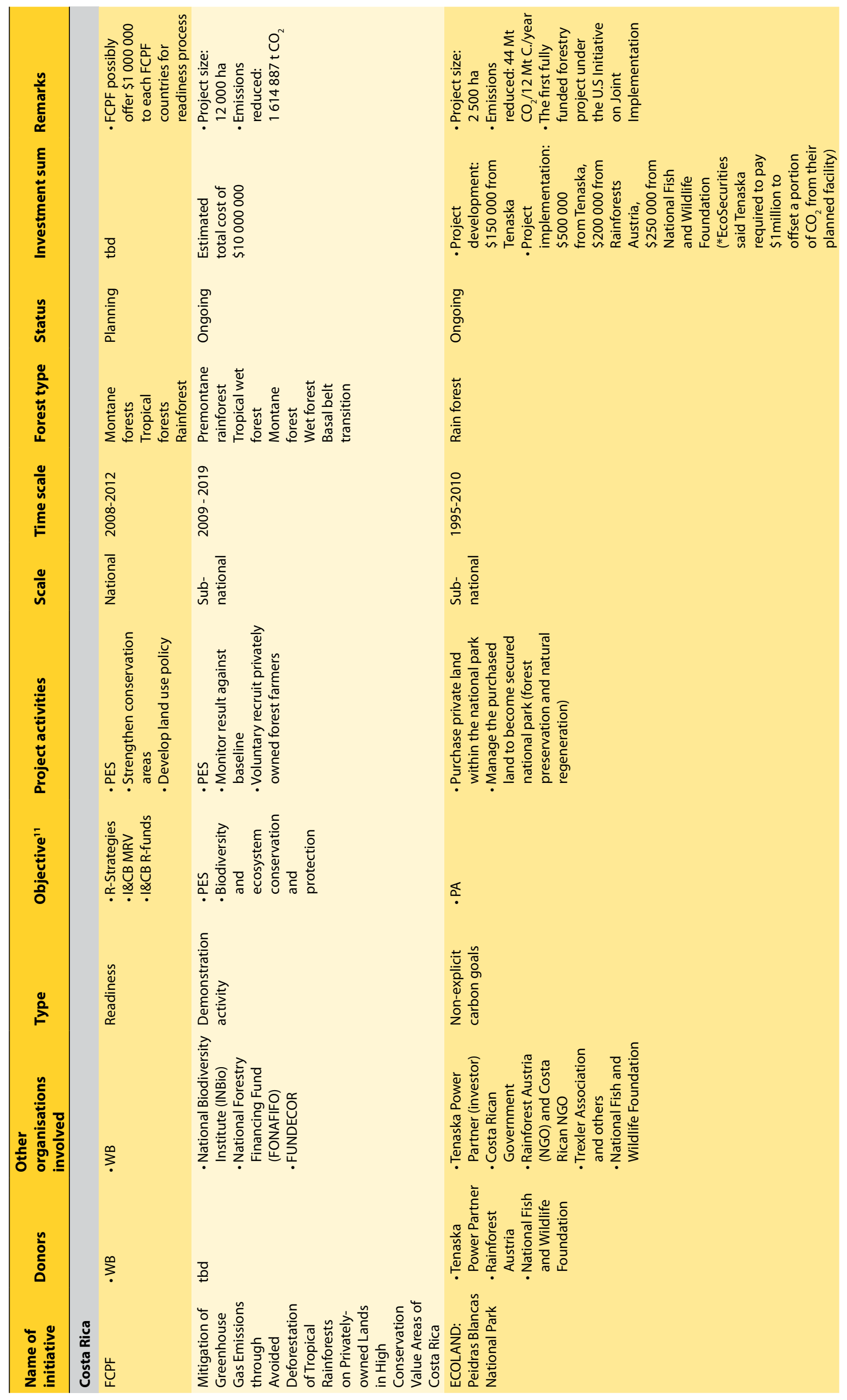




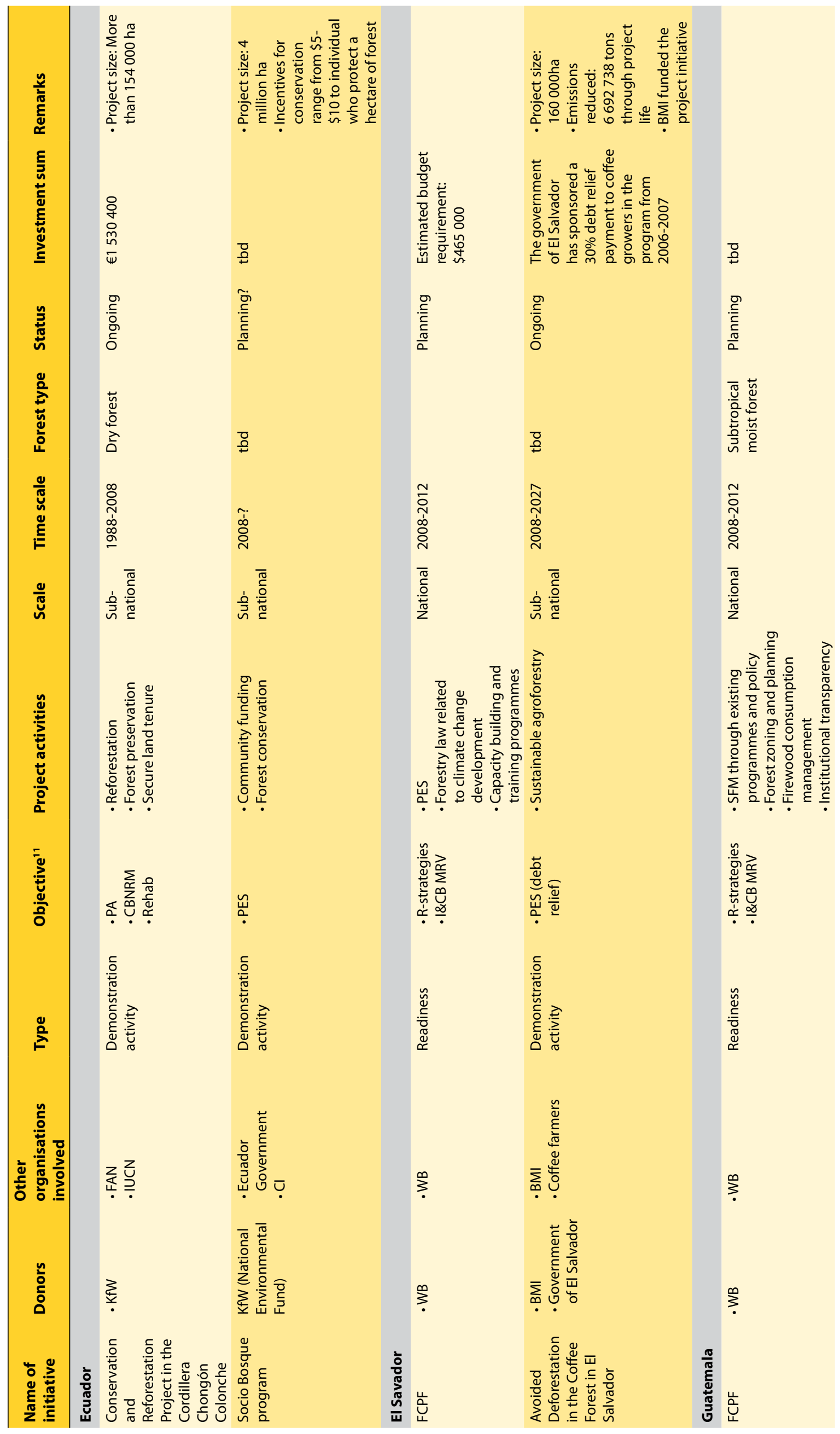




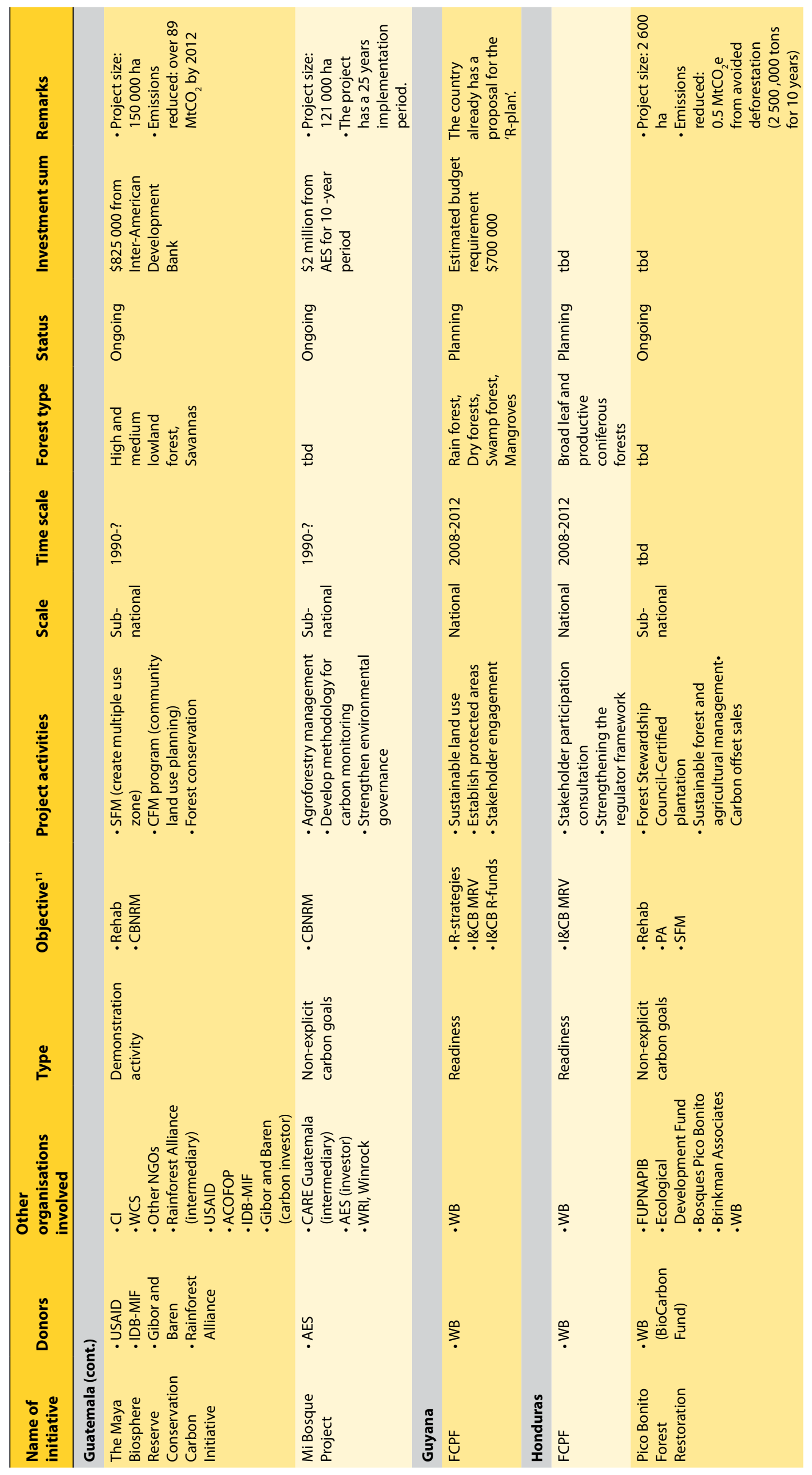




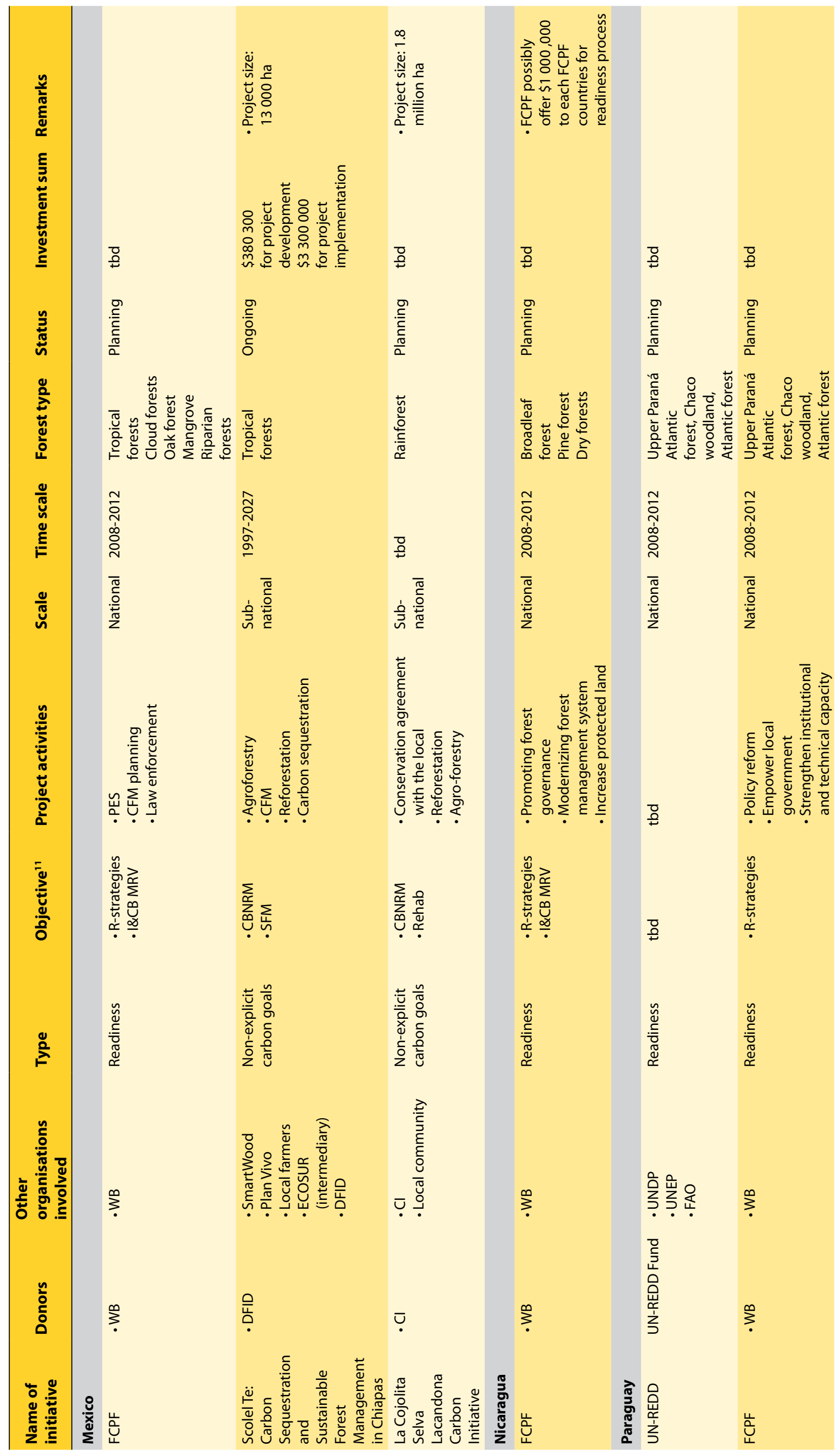




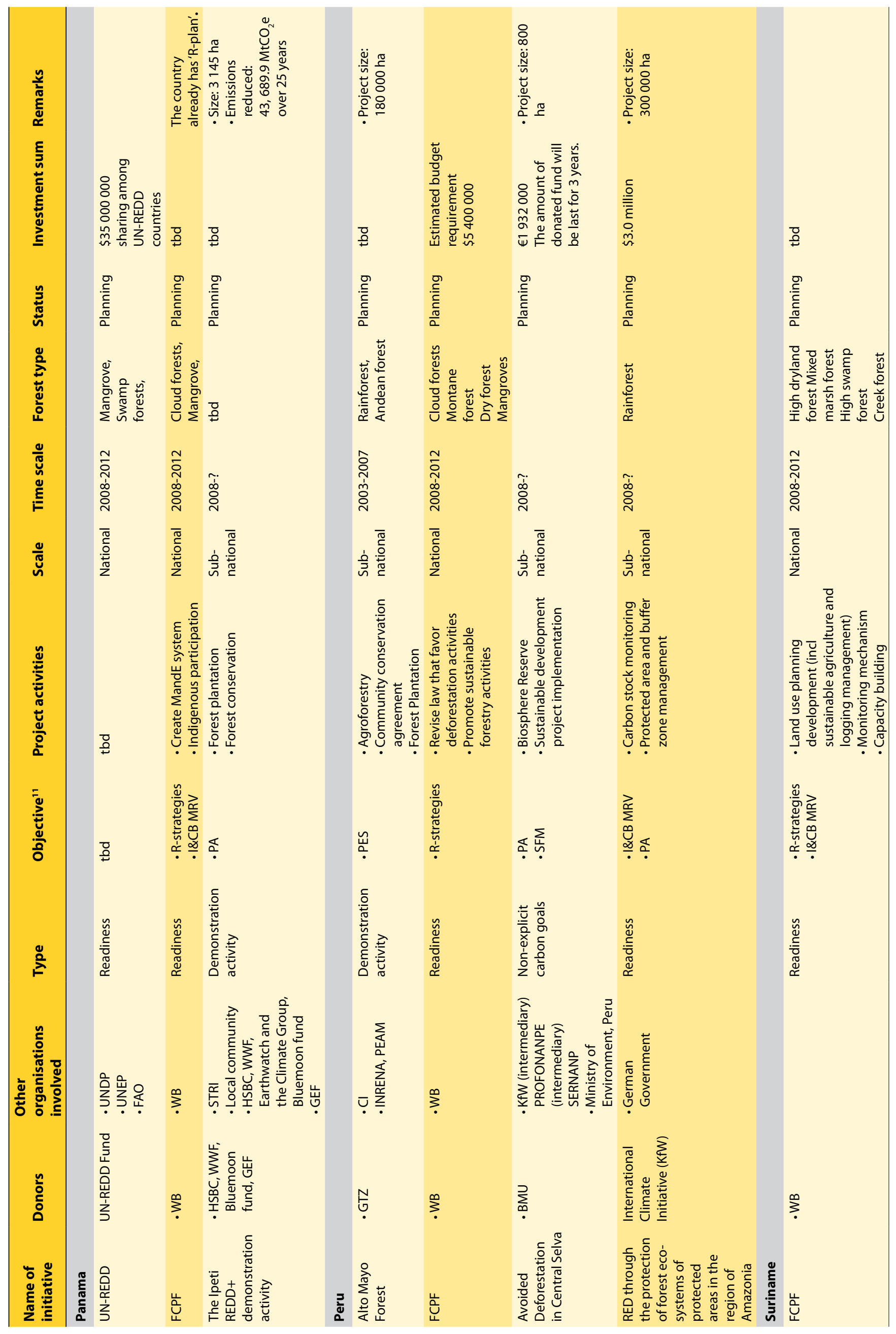





\section{Center for International Forestry Research}

CIFOR advances human wellbeing, environmental conservation and equity by conducting research to inform policies and practices that affect forests in developing countries. CIFOR is one of 15 centres within the Consultative Group on International Agricultural Research (CGIAR). CIFOR's headquarters are in Bogor, Indonesia. It also has offices in Asia, Africa and South America.

To request a copy of this publication, please contact cifor@cgiar.org

\section{www.cifor.cgiar.org}

